\title{
Identification of 1, 2, 4-triazine and its derivatives against Lanosterol 14 - demethylase (CYP51) property of Candida albicans: Influence on the development of new antifungal therapeutic strategies
}

Abhishek Kumar Verma ${ }^{1 a^{*}}$, Aarfah Majid ${ }^{2 b}$, Md. Shahadat Hossain ${ }^{3 a}$, Sk. Faisal Ahmed ${ }^{3 a}$, Mohammad Ashid ${ }^{2 b}$, Ali Asger Bhojiya ${ }^{4 b}$, Satish Ameta ${ }^{5 b}$, Sudhir K. Upadhyay ${ }^{6 b}$, Abhishek K.Srivastava ${ }^{7 b}$, Naveen Kumar Vishvakarma ${ }^{8 b}$, Vijay Kumar Yadav ${ }^{9 b}$, Pankaj Kumar Teli ${ }^{1 b}$, Harina ${ }^{1}$, Mudassir Alam ${ }^{10}$

${ }^{1}$ Department of Life Sciences, Faculty of Science and Technology, Mewar University, Gangrar, Chittorgarh, Rajasthan, India

${ }^{2}$ Department of Chemistry, Faculty of Science and Technology, Mewar University, Gangrar, Chittorgarh, Rajasthan, India

${ }^{3}$ Department of Biotechnology and Genetic Engineering, Noakhali Science and Technology University, Noakhali, Bangladesh

${ }^{4}$ Department of Agriculture and Veterinary Sciences, Mewar University, Gangrar, Chittorgarh, Rajasthan, India

${ }^{5}$ Department of Environmental Science, Faculty of Science and Technology, Mewar University, Gangrar, Chittorgarh, Rajasthan, India

${ }^{6}$ Department of Environmental Science, V.B.S. Purvanchal University, Jaunpur, Uttar Pradesh, India

${ }^{7}$ Department of Biotechnology, M.H.P.G. College, Jaunpur, Uttar Pradesh, India

${ }^{8}$ Department of Biotechnology, Guru Ghasidas Vishwavidyalaya, Koni, Bilaspur, Chhattisgarh, India

${ }^{9}$ Department of Forestry, Faculty of Agriculture and Veterinary Science, Mewar University, Gangrar, Chittorgarh, Rajasthan, 312901, India

${ }^{10}$ Department of Zoology, Aligarh Muslim University, Aligarh, Uttar Pradesh, India

*Correspondence Address

abhishekbairwa913@gmail.com, abhishek.kumar@mewaruniversity.co.in

${ }^{\text {a} E q u a l ~ f i r s t ~ a u t h o r ~ c o n t r i b u t i o n ~}$

${ }^{b}$ Equal second author contribution

\begin{abstract}
This research aims to find out whether the synthetic 1,2, 4-triazine and its derivatives have antifungal effects and can protect humans from infection with Candida albicans. Molecular docking and molecular dynamic simulation are widely used in modern drug design to target a We are interested in using molecular docking and molecular dynamics modelling to investigate the interaction between the derivatives of 1,2, 4-triazine and the resulting Lanosterol 14 demethylase (CYP51) of Candida albicans The inhibition of Candida albicans CYP51 is the main goal of our research. The 1,2, 4-triazine and its derivatives have been docked to the CYP51 enzyme, which is involved in Candida albicans Multidrug Drug Resistance (MDR). Autodock tools were used to identifying the binding affinities of molecules against the target proteins. Compared to conventional fluconazole, the molecular docking results indicated that each drug has a high binding affinity for CYP51 proteins and forms unbound interactions and hydrogen bonds with their active residues and surrounding allosteric residues. The docking contacts were made using a $10 \mathrm{~ns}$ MD simulation with nine molecules. RMSD, RMSF, hydrogen bonds, and the Rg all confirm these conclusions. In addition, these compounds were expected to have a favorable pharmacological profile and low toxicity. The compounds are being offered as scaffolds for the development of new antifungal drugs and as candidates for future in vitro testing.
\end{abstract}

Key Words: 1, 2, 4-Triazine; Lanosterol 14a-demethylase (CYP51); Drug Resistance; Molecular Docking; Molecular Dynamic Simulation. 


\section{Introduction}

Candida species, the most common of which are C. albicans, cause most of the fungal infections in humans. The presence of Candida albicans is noteworthy. Candida albicans is often found as part of the normal microbiota in the human intestine, but can cause life-threatening infections in immunocompromised people such as HIV patients [1]. Candida species can also cause bloodstream infections, and with the increase in candida infections in recent years, multi-drug resistance (MDR) has become a major public health problem [2-3]. MDR is a property in which cells become resistant to multiple chemotherapy drugs that are not chemically related at the same time. Drug efflux pumps from the ATP-Binding Cassette (ABC) or Major Facilitator Superfamily (MFS) families play an important role in establishing and maintaining drug tolerance. Because of their rapid expulsion, induced overexpression of genes that produce these transporter proteins is unable to enable cells to maintain dangerous levels of the drug, rendering it unusable [3-6].

Lanosterol-14-demethylase (CYP51) belongs to the cytochrome P450 superfamily of monooxygenases, which catalyzes the oxidative removal of the 14-methyl group (C-32) from lanosterol to give 14, 15-desaturated intermediates in ergosterol biosynthesis in fungi produce kingdoms, CYP51 is an important enzyme in sterol biosynthesis, which fulfills metabolic functions such as membrane permeability, membrane fluidity, enzyme activity, cell shape and progression of the cell cycle [7-9]. This enzyme occurs in all eukaryotes (including humans) and because azoles also interact with other cytochrome P450-dependent enzymes (CYP3A4), a specific inhibition of the enzyme is decisive for a higher therapeutic index [1013], the hydrophilic H-bond region, and thus the small hydrophobic gap formed. The affinity of azole antifungals for Lanosterol 14ademethylase is determined not only by the coordinative binding of the nitrogen of the azole ring to the heme iron within the active side (N-4 of triazole and N-3 of imidazole), but also by the affinity of the N1 substituent to the apoprotein, which is part of the remainder of the azole antifungal agent fits into the hydrophobic groove of CYP51 in the same way as Lanosterol [1419].

1,2,4-Triazine and its derivatives can be a common core structural system found in a variety of physiologically active chemicals, including antifungal and antibacterial activity, and are also known to move pharmacologically [20]. 
The aim of this work was to use a computer-aided drug discovery strategy to find 1, 2, 4-triazine and its derivatives that have the potential to inhibit the protein Candida albicans Lanosterol 14demethylase (CYP51).

\section{Materials and Methodology}

\section{Protein Preparation}

The protein database (https://www.rcsb.org/) was used to obtain the structure of Lanosterol 14 Demethylase (CYP51) (PDB ID: 4LXJ) [21] .PDB is a database containing information about experimental proteins and nucleic acid structures. Water molecules were removed with PyMOL (Figure 1). PyMOL is an open source software program that can be used to create molecular graphics [22].

\section{Ligand Preparation}

The 1, 2, 4-triazine and its derivatives were selected for their potential pharmacological and therapeutic benefits (Figure S1) [20]. Docking research was conducted against fluconazole, a controlled drug that may be a potent CYP51 inhibitor and is commonly given to mycoses. The structures of the control drug fluconazole were retrieved from the PubChem database. The PubChem database contains data on chemical compounds, including their structure, formula, molecular weight etc. (https://pubchem.ncbi.nlm.nih.gov/source/15751) [23]. ChemDraw software was used to create all derived connections in mol file. The structures were first called up in SDF format and then translated into PDB format using PyMOL, an open source system program for molecular visualization [22].

\section{Binding Site Prediction}

The Computed Atlas for Surface Topography of Proteins was used to identify the amino acids that are involved in the formation of active pockets (CASTp). CASTp could be a simple and helpful web-based tool for the identification of protein structures and site pockets [24]. Determining the location is crucial for aligning the mesh box before docking.

\section{Molecular Docking}

The molecular docking simulations were performed using Auto Dock (The Scripps Research Institute, La Jolla, CA, USA). It is widely used as open software for molecular docking and significantly increases the accuracy of binding mode predictions compared to Auto Dock 4 [2528] and site residues of the proteins were estimated using the web-based CASTp tool. The size () 
of the lattice box in lanosterol-14-demethylase (CYP51) was 88.63, 86.49 and 60.53, while the middle (x, y and $\mathrm{z}$ ) of the lattice box was 22.01, 14.21 and 19.82.

\section{Analysis and Visualization of Docking Results}

The docked posture with the best negative score was selected as the best for the appropriate chemical and protein after the docking simulation. PyMOL Molecular Graphics System 2.0 [22] and Discovery Studio 4.5 [29] were used to display and score the best docked posture to study unbound interactions.

\section{Molecular Dynamic (MD) Simulation}

Molecular dynamics calculations were used to determine the physical motions of atoms and molecules in a protein-ligand-docked complex. The nine molecules were selected for a 10nsMD simulation. The docked complexes were constructed using the steepest descent minimization module, the YASARA energy minimization module (YASARA Biosciences, GmbH) and the AMBER force field (Assisted Model Building with Energy Refinement) [30-31] before proceeding with the MD simulation Force field, $298 \mathrm{~K}$ temperature, 1 bar pressure, Coulomb electrostatics with a cut-off of $7.86,0.9 \% \mathrm{NaCl}$, solvent density $0.997, \mathrm{pH} 7.0,1$-fs time steps, periodic boundaries and all mobile atoms were used in the MD simulation [32-33]. The binding energy, the root mean square deviation (RMSD), the root mean square fluctuation (RMSF), the radius of gyration $(\mathrm{Rg})$ and the total number of $\mathrm{H}$-bonds were measured with MD determines simulations in the same way as in previous research [34-36].

\section{MMPBSA Calculations}

Molecular mechanics / Poisson-Boltzmann surface (MMPBSA) [37] is one of the most frequently used methods for calculating the binding free energy of a protein-ligand combination. The stable region of the nine molecules with CYP51 complexes was used to construct a $10 \mathrm{~ns}$ MD trajectory for MM-PBSA calculations. The MMPBSA method of the YASARA simulator was used to measure the binding energy components (YASARA Biosciences, GmbH). The g_mmpbsa tool uses the following equation to calculate the binding energy of the protein-ligand complex-

$\Delta \mathrm{G}_{\text {Binding }}=\mathrm{G}_{\text {Complex }}-\left(\mathrm{G}_{\text {Protein }}+\mathrm{G}_{\text {Ligand }}\right)$

Where $\mathrm{G}_{\text {Complex }}$ denotes the binding complex's total free energy, and GProtein and $\mathrm{G}_{\text {Ligand }}$ denote the total free energies of the nine molecules bound to Lanosterol 14--demethylase (CYP51), respectively.

\section{Prediction of Pharmacological Properties}


The DruLito software was used to predict the drug-like properties of the compounds. To demonstrate their pharmacological integrity, orally active drugs should have certain commonly used drug-like properties the number of rotatable bonds and Lipinski's rule violations of 5 [38] were determined during this research. In accordance with a previously described method [39], the absorption (\% ABS) was calculated using the following formula:

$$
\% \text { ABS }=109-(0.345 \times \text { TPSA }) \text {. }
$$

\section{Prediction of Toxicological Properties}

Since drug toxicity is an important issue, we used the admetSAR online toolbox (http://lmmd.ecust.edu.cn:8000/) to predict toxicological properties of the compounds that were critical and Predictors are helpful in drug development [40]. Table 7 summarizes the data including Ames toxicity, carcinogenic properties, acute oral toxicity, acute rat toxicity, and inhibitory effects on hERGa.

\section{Result and Discussion}

Binding Site Analysis

CASTp was used to identify the active site pockets in lanosterol-14-demethylase (CYP51). CASTp could be a web-based tool for determining the aminoalkanoic acid residues in the active site of a protein. For CYP51, the CASTp results are shown in Figures S1 and S3. Only the amino acids within the site and their positions are given in Table 1 for CYP51 based on the CASTp findings.

\section{Dock score of 1, 2, 4- Triazine and its derivatives against CYP51}

The crystal structure of CYP51 from Candida albicans (PDB id-4LXJ) was used for docking. The enhanced precision (XP) mode of lattice-based ligand docking with energetics was used to achieve the blind docking of molecules. For the docking we used 1, 2, 4-triazine and its derivatives (molecule 19) (Figure S2). Here we showed that molecules that systematically docked to lanosterol-14-demethylase (Table 2) have the separation energy (CYP51). Figures 1 to 3 provide a three-dimensional representation of docked complexes.

We observed that all compounds had the best binding affinities, as indicated in Table 2, compared to the control inhibitor fluconazole (-8.1 for CYP51). For lanosterol 14 - demethylase (CYP51) they showed promising binding affinities with variable binding free energies in the range from 8.2 to -11.9 . Based on the binding affinities, the molecules could be classified as Molecule 6> Molecule 4 Molecule 9> Molecule 5> Molecule 7> Molecule 8> Molecule 1> Molecule 3> Molecule 2 for CYP51.

Protein ligand interactions of 1, 2, 4- Triazine and its derivatives against CYP51 
Protein-ligand interactions are highlighted by hydrophobic interactions, hydrogen bonds, electrophoresis, and van der Waals interactions, all of which are essential for predicting ligand binding affinities with proteins. All compounds exhibited a variety of unbound and bound interactions with multiple site residues or at the edge of the site. With the ligand atoms given in Table 3, Thr A: 507, Arg A: 98, Phe A: 506, Ser A: 508, Met A: 509 and His A: 468 mainly formed conventional chemical bonds and a carbon-hydrogen. All molecules showed hydrophobic interactions with various amino acids via the formation of -, - stacked, or -alkyl bonds (Figures 1 to 3). It has been discovered that many amino acids are involved in hydrophobic interactions, van der Waals interactions, and hydrogen bonds. In addition, the ligands bind with the CYP51 site or the near site mainly through hydrophobic interactions. Hydrophobic interactions have effectively identified certain functional groups that are responsible for the hydrophobically producing effect of compounds with high binding affinity for target proteins and that should have a significant impact on Candida albicans infection.

MD simulations can be used to explain hydrogen bonds and hydrophobic properties as well as molecular processes of ligand-protein interactions depending on the flexibility of ligands or proteins. Today this method is often used in the development of biomolecules and active substances [41-42]. After molecular docking, we performed an MD simulation with targeted enzymes for all nine molecules, since all nine molecules have good dock scores compared to the standard inhibitor fluconazole.

\section{Molecular Dynamic Simulation}

The MD simulation was performed for $10 \mathrm{~ns}$ on nine molecules in conjunction with lanosterol 14 - demethylase (CYP51) in solute and solvent. The aim was to study the dynamic properties of lanosterol-14-demethylase (CYP51) with the nine compounds to see if structural changes related to the inhibition mechanism were observed. Conformational changes in simulated solute molecules cause density fluctuations in 10 ns. If the simulation box is always the same size, density fluctuations lead to changes in pressure. As a result, the cell is rescaled during the simulation to maintain constant cell pressure. In our study, the simulation lengths of all nine molecules with complex lanosterol-14-demethylase (CYP51) are between 128.34 and 128.52 (Figure S4).

The total potential energy of Lanosterol 14-demethylase (CYP51) with the nine molecules was measured to determine the equilibrium and stability of the systems. Figure S5 shows the total potential energy of Lanosterol 14 - demethylase (CYP51) with the nine-molecule complex in 10 ns. Binding energies (Bond), binding angle energies (Angle), dihedral energies (Diehedral), 
planarity or false dihedral energies (planarity), van der Waals energies (VdW), electrostatic energies (Coulomb) and distribution energies are all potential energy components of all proteinligand complexes in KJ / mol versus time intervals. Figure S6 shows the surface of the dissolved Lanosterol 14 demethylase (CYP51) vs. the time interval of all complexes Vander Waals surface (SurfVdW), molecular surface (SurMol) and surface accessible to solvents (SurfAcc). Figure S7 shows the surface area of the dissolved lanosterol 14 - demethylase (CYP51) calculated using nine molecules.

\section{Structural deviations and Compactness}

A tiny chemical can produce wide-ranging conformational changes in a protein once it has been bound. One of the most important features for analyzing protein structure changes and dynamic activity is the root mean square deviation (RMSD) [26]. Complex remained stable. The calculated RMSD values of lanosterol-14-demethylase (CYP51) are 2.35, 5.00, 5.00, 5.00, 7.00, 6.00, 4.00 and 4.5 (Figure 4) . RMSD data show no significant change in the RMSD values of the CYP51 complex with nine molecules. These results show that the overall system remained stable during the MD simulation.

The mean fluctuation of each residue was quantified as the root mean square fluctuation (RMSF) to study the residual vibrations in lanosterol 14-demethylase (CYP51) before and after the binding of the nine substances (Figure 5). Random residual fluctuations were detected in CYP51 from the N-terminal to the C-terminal regions. These variations were shown in solute and solvent for each CYP51 backbone residue beyond nine. The residual fluctuations of CYP51 with nine molecular complexes were found to be 2.96, 1.93, 8.54, 2.66, 2.31, 1.44, 1.42, 2.45 and 1.26 inches. According to the RMSF map, residual fluctuations in the area where nine molecules bind show slight variations. After the nine molecules have attached, however, CYP51 shows less increased fluctuations, which is probably due to conformational changes in the binding pocket of the protein. The radius of gyration $(\mathrm{Rg})$ is a measure of the compactness and folding behavior of a protein, linked to its tertiary structure and the general state of conformation. By estimating the $\mathrm{Rg}$ of both Lanosterol 14 - demethylase (CYP51) and the nine-molecule complex, we were able to determine their stability. For nine molecules the Rg stayed between 26.3-27.4, 25.2-27.0, 25.826.7, 25.4-27.6, 25.8-26.8, 25 , 8-26.9, 25.4-27.4, 25.3-26.6 and 25.8-27.1 during the simulation period (Figure 6). No structural change was detected in lanosterol-14-demethylase (CYP51) in the presence of the nine compounds, and it reached a stable Rg equilibrium, which indicates a complex stability across the simulation track. 
A complicated cross-correlation matrix represents the correlative movements of various bag remnants. Figure 7 shows the correlated residual movement of all simulated protein-ligand complexes. Heat maps with high color intensity were used to depict these linked movements between the remains of the bag. Colors ranging from blue (-1, fully anti-correlated) to yellow $(+1$, fully correlated) are used to visualize DCCM, with blue and red lines separating high, anti, and correlated pairings.

\section{Dynamics of CYP51Interactions: Hydrogen bond analysis}

The stability of the three-dimensional structure of a protein is determined by intramolecular hydrogen bonds within the molecule. By studying the stability of the protein-ligand complex, hydrogen bond analysis can be used to assess molecular recognition, directionality, and specificity of interactions [26]. We calculated the kinetics of intramolecular hydrogen bond pairs within 10 ns to determine the stability of CYP51 to validate Lanosterol 14 - demethylase with nine molecules docked complex. The solute-solvent hydrogen bonds for all nine molecules with lanosterol-14demethylase (CYP51) complexes are shown in Figure 8 at $10 \mathrm{~ns}$ intervals.

\section{Analysis Secondary Structure Dynamics of CYP51}

Conformational changes are caused by varying degrees of secondary structural dynamics remaining in a protein structure. Observing variations in the secondary structure composition of a polypeptide chain could help researchers better understand its conformational behavior and its folding process. We looked at the dynamics of CYP51 secondary structure content before and after all nine molecules were bound to see how stable it was. The helix, leaflet, and convolutions comprising the secondary structure of Lanosterol 14 demethylase (CYP51) were broken down into individual residues at each time point and the average number of residues making up the secondary structure was shown as a function of the total fraction of alpha helices, beta sheets, turns, coils, 310 helices, and pi helices in all nine molecular complexes ranged from 0.0 to $50 \%$ at $10 \mathrm{~ns}$ time intervals for all nine molecular complexes (Figure 9). Figure 10 shows the secondary structure of protein per residue for protein-ligand complexes from 00 to 550 at time intervals of $10 \mathrm{~ns}$. After all nine molecules were attached, no changes in the secondary structure composition of CYP51 were found over a period of $10 \mathrm{~ns}$, suggesting that the complexes are very stable.

\section{MPBSA Analysis -}

The MM / PBSA method was used to calculate the binding energy of the complex structure using ensembles derived from the MD simulation. The binding energy values for lanosterol-14demethylase (CYP51) with nine molecules are shown in Figure 11 and Table S1. 


\section{Pharmacokinetics and Toxicological Properties analysis}

The ADME / T properties of ligands must be known in order to determine their drug similarity. The DruLito software was used to evaluate the pharmacological properties of 1, 2, 4-triazine and its derivatives (Figure 12). It can detect molecules using drug similarity rules like Lipinski's rule, MDDR-like rule, Ghose filter, BBB similarity, CMC-50-like rule, unweighted QED, Veber filter, and weighted QED calculate and filter. Table 4 summarizes the results. Table 5 shows the expected uptake, distribution and metabolism of 1, 2, 4-triazine and its derivatives using the admetSAR server. All compounds were found to be non-substrate for P-glycoprotein (P-gp) substrate, yes for Caco-2 permeability, yes for Blood Brian Barrier (BBB) and non-substrate for CYP4502C9, CYP4502D6 substrate. With the exception of molecule 2, all compounds are non-substrates for CYP4503A4. Table No. 6 shows that all compounds have significant CYP inhibitory promiscuity.

SWISS ADME boiled egg diagram (Figure 13) enables the evaluation of HIA as a function of the position of the ten molecules within the WLOGP-Versus-TPSA reference. Molecule 1 (control), molecules 8 are predicted to be absorbed by the gastrointestinal tract (white region) but not penetrate the brain (egg yolk). Molecules 1 to 10 are not subject to any active efflux (red point). The admet website was used to predict the toxicological properties of all compounds (Table 7). The results indicated that, with the exception of molecule 3, none of the compounds posed an AMES toxicity problem and that all of the molecules are non-carcinogenic. On the other hand, all compounds were found to be weak inhibitors of the human ether-a-go-go-related gene (HERGa) and have a low risk of acute toxicity. In accordance with the expected acute oral toxicity, all compounds are classified in Class III based on their expected acute oral toxicity (Table 7). It is possible that the combination of these chemicals can be predicted, and it is a good idea to stop the mycosis.

In the overall studies, the PDB was used to find the crystal structure of lanosterol-14-demethylase (CYP5). Antifungal and antibacterial activities against strains of 1, 2, 4-triazine and its derivatives were carried out by Aarfah Majid et al., 2020 [20], and these compounds showed good antifungal activity compared to control fluconazole. Our research shows that all 1,2, 4-triazines and its derivatives have potent inhibitory effects against lanosterol-14-demethylase (CYP51) from Candida albicans. 
Computational engineering can filter the best ligands from a wide variety of compounds, simplifying the drug development process. After that, further clinical research with experimental animals and further in vivo studies are required. All of the basic information needed to develop novel antifungal treatments to block Ergosterol biosynthesis will be included in the study. Diseases caused by eukaryotic organisms such as fungi are more difficult to treat than infections caused by bacteria. Antifungal drugs that can discover unique targets that are not shared with human hosts are few and far between. Due to the lack of chitin structure in human cells, the fungal cell wall remains an untapped therapeutic target for selective antimycotics [43-44]. Most treatments are aimed at treating fungal infections and target the Ergosterol production route or its end product Ergosterol, a membrane sterol found only in fungi. It is the primary sterol and is therefore needed for fungal cell development and proper membrane function. It contributes to the correct activity of membrane-bound enzymes and also acts as a bio regulator of membrane fluidity, asymmetry and integrity [45]. As a result, efficient antifungal drugs and the discovery of a potential target to treat them will become possible. Diseases are urgently needed. One of the most important proteins in mycoses is lanosterol-14-demethylase (CYP51). As a result of this discovery, this protein has been identified as a potential therapeutic target.

\section{CONCLUSION}

With Lanosterol 14 - demethylase (CYP51) we were able to show for the first time that derivatives of 1, 2, 4-triazine can play a decisive role in the prevention of mycoses in in-silico research. Compared to the conventional inhibitor fluconazole, all derivatives of 1, 2, 4-triazine showed stronger binding affinities to the target protein. We discovered that all compounds can act as inhibitors against a specific protein of Candida albicans, based on molecular docking and chemical bonding, hydrophobic interactions and van der Waals interactions nine molecules with the protein Lanosterol 14 - demethylase (CYP51). Their drug-like properties have been demonstrated through physicochemical, pharmacokinetic, and toxicological characteristics, which have proven them to be safe sources of drugs. Overall, we conclude that 1,2, 4-triazine and its derivatives, either alone or in combination with the different compounds, can target CYP51 or may be beneficial for future antifungal drug development.

\section{Acknowledgement}


The authors are thankful to Dr. Ashok kumar Gadiya, Chairman, Mewar University, Gangrar, Rajasthan for his continues support and assistance throughout the work. Department of Life Sciences and Chemistry, Faculty of Science \& Technology, and Mewar University for providing necessary infrastructure facilities. AKV acknowledges the Department of Biotechnology and Genetic Engineering, Noakhali Science and Technology University for conducting MD Simulation.

Conflict of Interest- The authors declare that they have no known competing financial interests or personal relationships that have appeared to influence the work reported in this manuscript.

Funding: This research received no external funding.

\section{References}

1. H. Tang, C. Zheng, J. Lv et al., "Synthesis and antifungal activities in vitro of novel pyrazino [2, 1-a] isoquinolin derivatives," Bioorganic \& Medicinal Chemistry Letters, vol. 20, no. 3, pp. 979-982, 2010.

2. W. Wang, C. Sheng, X. Che et al., "Design, synthesis, and antifungal activity of novel conformationally restricted triazole derivatives," Archiv der Pharmazie, vol. 342, no. 12, pp. 732-739, 2009.

3. H. A. Ghabbour, M. M. Qabeel, W. M. Eldehna, A. Al-Dhfyan, and H. A. Abdel-Aziz, "Design, synthesis, and molecular docking of 1-(1-(4-chlorophenyl)-2(phenylsulfonyl)ethylidene)-2- phenylhydrazine as potent nonazole anticandidal agent," Journal of Chemistry, vol. 2014, Article ID 154357, 2014.

4. S. Emami, T. Banipoulad, H. Irannejad et al., "Imidazolylchromanones containing alkyl side chain as lanosterol $14 \alpha$ - demethylase inhibitors: Synthesis, antifungal activity and docking study," Journal of Enzyme Inhibition and Medicinal Chemistry, vol. 29, no. 2, pp. 263-271, 2014.

5. R. S. Kankate, P. S. Gide, and D. P. Belsare, "Design, synthesis and antifungal evaluation of novel benzimidazole tertiary amine type of fluconazole analogues," Arabian Journal of Chemistry, 2014.

6. A. Ahmad, A. Khan, N. Manzoor, and L. A. Khan, "Evolution of ergosterol biosynthesis inhibitors as fungicidal against Candida," Microbial Pathogenesis, vol. 48, no. 1, pp. 3541, 2010. 
7. C. Sheng, Z. Miao, H. Ji et al., "Three-dimensional model of lanosterol $14 \alpha$-demethylase from Cryptococcus neoformans: Active-site characterization and insights into azole binding," Antimicrobial Agents and Chemotherapy, vol. 53, no. 8, pp. 3487-3495, 2009.

8. Q. Zhang, D. Li, P. Wei et al., "Structure-based rational screening of novel hit compounds with structural diversity for cytochrome P450 sterol $14 \alpha$-demethylase from penicillium digitatum," Journal of Chemical Information and Modeling, vol. 50, no. 2, pp. 317-325, 2010.

9. S. Jacob K, S. Ganguly, P. Kumar, R. Poddar, and A. Kumar, "Homology model, molecular dynamics simulation and novel pyrazole analogs design of Candida albicans CYP450 lanosterol $14 \alpha$-demethylase, a target enzyme for antifungal therapy," Journal of Biomolecular Structure and Dynamics, vol. 35, no. 7, pp. 1446-1463, 2017.

10. I. S. Dogan, S. Sarac `, S. Sari et al., "New azole derivatives showing antimicrobial effects and their mechanism of antifungal activity by molecular modeling studies," European Journal of Medicinal Chemistry, vol. 130, pp. 124-138, 2017.

11. K. K. Reddy, S. K. Singh, S. K. Tripathi, C. Selvaraj, and V. Suryanarayanan, "Shape and pharmacophore-based virtual screening to identify potential cytochrome P450 sterol $14 \alpha$ demethylase inhibitors," Journal of Receptors and Signal Transduction, vol. 33, no. 4, pp. 234-243, 2013.

12. A. Stana, D. C. Vodnar, R. Tamaian et al., "Design, synthesis and antifungal activity evaluation of new thiazolin-4-ones as potential lanosterol $14 \alpha$-demethylase inhibitors," International Journal of Molecular Sciences, vol. 18, no. 1, article no. 177, 2017.

13. A. G. S. Warrilow, J. G. L. Mullins, C. M. Hull et al., "S279 point mutations in Candida albicans sterol 14- $\alpha$ demethylase (CYP51) reduce in vitro inhibition by fluconazole," Antimicrobial Agents and Chemotherapy, vol. 56, no. 4, pp. 2099-2107, 2012.

14. A. A. Sagatova, M. V. Keniya, R. K. Wilson, M. Sabherwal, J. D. A. Tyndall, and B. C. Monk, "Triazole resistance mediated by mutations of a conserved active site tyrosine in fungal lanosterol 14 $\alpha$-demethylase," Scientific Reports, vol. 6, Article ID 26213, pp. 1-6, 2016.

15. C. Sheng, W. Zhang, M. Zhang et al., "Homology modeling of lanosterol $14 \alpha$ demethylase of Candida albicans and Aspergillus fumigatus and insights into the enzymesubstrate interactions," Journal of Biomolecular Structure and Dynamics, vol. 22, no. 1, pp. 91-99, 2004. 
16. Y. Jiang, J. Zhang, Y. Cao et al., "Synthesis, in vitro evaluation and molecular docking studies of new triazole derivatives as antifungal agents," Bioorganic \& Medicinal Chemistry Letters, vol. 21, no. 15, pp. 4471-4475, 2011.

17. D. J. Sheehan, C. A. Hitchcock, and C. M. Sibley, "Current and emerging azole antifungal agents," Clinical Microbiology Reviews, vol. 12, no. 1, pp. 40-79, 1999.

18. Jadhav, A. K., Khan, P. K., \& Karuppayil, S. M. (2020). Phytochemicals as Potential Inhibitors of Lanosterol 14 A-Demethylase (Cyp51) Enzyme: An In Silico Study on Sixty Molecules. International Journal of Applied Pharmaceutics, 12(4), 18-30. https://doi.org/10.22159/ijap.2020.v12s4.40100

19. Verma, A.K., Maurya, S.K., Kumar, A., Barik, M., Yadav, V., Umar, B., Lawal, M., Usman, Z.A., Adam, M.A. and Awal, B., 2020. Inhibition of multidrug resistance property of Candida albicans by natural compounds of parthenium hysterophorus L. An In-Silico approach. Journal of Pharmacognosy and Phytochemistry, 9(3), pp.55-64.

20. Majid, A., Ashid, M. and Hussain, N., 2020. A Convenient Synthesis and Reactions ofsome Substituted 1, 2, 4-Triazine, and Their Derivatives with Carbazole, Sulfonamide and Trityl Chloride Moiety of Biological Interest. European Journal of Molecular \& Clinical Medicine, 7(8), pp.994-1004.

21. RCSB Protein Data Bank [Internet].

22. Yuan, S., Chan, H. S., \& Hu, Z. (2017). Using PyMOL as a platform for computational drug design. Wiley Interdisciplinary Reviews: Computational Molecular Science, 7(2), e1298.

23. RCSB PubChem Database [Internet].

24. Tian W, Chen C, Lei X, Zhao J, Liang J. CASTp 3.0: computed atlas of surface topography of proteins. Nucleic Acids Res. 2018 Jul 2;46(W1):W363-W367. doi: 10.1093/nar/gky473. PMID: 29860391; PMCID: PMC6031066.

25. Trott, O., \& Olson, A. J. (2010). AutoDock Vina: improving the speed and accuracy of docking with a new scoring function, efficient optimization, and multithreading. Journal of computational chemistry, 31(2), 455-461. https://doi.org/10.1002/jcc.21334

26. Verma, A. K., Ahmed, S. F., Hossain, M. S., Bhojiya, A. A., Mathur, A., Upadhyay, S. K., ... \& Bahadur, N. M. (2021). Molecular docking and simulation studies of flavonoid compounds against PBP-2a of methicillin-resistant Staphylococcus aureus. Journal of 
Biomolecular Structure and 1-17. https://doi.org/10.1080/07391102.2021.1944911

27. Lawal, M., Verma, A. K., Umar, I. A., Gadanya, A. M., Umar, B., Yahaya, N., \& Auwal, B. Analysis of New Potent Anti-Diabetic Molecules from Phytochemicals of Pistia Strateotes with Sglt1 and G6pc Proteins of Homo Sapiens For Treatment Of Diabetes Mellitus. An In Silico Approach.https://doi.org/10.9790/3008-1504025973

28. Maurya, S. K., Maurya, A. K., Mishra, N., \& Siddique, H. R. (2020). Virtual screening, $\mathrm{ADME} / \mathrm{T}$, and binding free energy analysis of anti-viral, anti-protease, and anti-infectious compounds against NSP10/NSP16 methyltransferase and main protease of SARS CoV2. Journal of receptor and signal transduction research,40(6), 605-612. https://doi.org/10.1080/10799893.2020.1772298

29. Biovia, D.S. Discovery Studio Modeling Environment; Dassault Systèmes: San Diego, CA, USA, 2015.

30. Krieger, E., \&Vriend, G. (2015). New ways to boost molecular dynamics simulations. Journal of computational chemistry, 36(13), 996-1007.doi: 10.1002/jcc.23899

31. Ahmad, S., Raza, S., Uddin, R., \&Azam, S. S. (2017). Binding mode analysis, dynamic simulation and binding free energy calculations of the MurF ligase from Acinetobacter baumannii. Journal of Molecular Graphics and Modelling, 77, 72-85.doi: 10.1016/j.jmgm.2017.07.024

32. Kumar, S. P., Patel, C. N., Jha, P. C., \& Pandya, H. A. (2017). Molecular dynamicsassisted pharmacophore modeling of caspase-3-isatin sulfonamide complex: Recognizing essential intermolecular contacts and features of sulfonamide inhibitor class for caspase-3 binding. Computational biology and chemistry, 71, 117128.DOI: 10.1016/j.compbiolchem.2017.08.006

33. Tietze, D., Kaufmann, D., Tietze, A. A., Voll, A., Reher, R., König, G., \&Hausch, F. (2019). Structural and dynamical basis of G protein inhibition by YM-254890 and FR900359: an inhibitor in action. Journal of Chemical Information and Modeling, 59(10), 4361-4373.doi: 10.1021/acs.jcim.9b00433

34. Elfiky, A. A., \&Azzam, E. B. (2020). Novel guanosine derivatives against MERS CoV polymerase: An in silico perspective. Journal of Biomolecular Structure \& Dynamics, $1-$ 12. https://doi.org/10.1080/07391102.2020.1758789 
35. Enayatkhani, M., Hasaniazad, M., Faezi, S., Guklani, H., Davoodian, P., Ahmadi, N., Einakian, M. A., Karmostaji, A., \& Ahmadi, K. (2020). Reverse vaccinology approach to design a novel multi-epitope vaccine candidate against COVID-19: An in silico study. Journal of Biomolecular Structure \& $\quad$ Dynamics, $1-$ 19.https://doi.org/10.1080/07391102.2020.1756411

36. Pant, S., Singh, M., Ravichandiran, V., Murty, U. S. N., \& Srivastava, H. K. (2020). Peptide-like and small-molecule inhibitors against Covid-19. Journal of Biomolecular Structure \& Dynamics, 1-15. https://doi.org/10.1080/07391102.2020.1757510

37. Homeyer, N., \& Gohlke, H. (2012). Free energy calculations by the molecular mechanics Poisson- Boltzmann surface area method. Molecular informatics, 31(2), 114122.https://doi.org/10.1002/minf.201100135

38. Lipinski, C.A.; Lombardo, F.; Dominy, B.W.; Feeney, P.J. Experimental and computational approaches to estimate solubility and permeability in drug discovery and development settings. Adv. Drug Deliv. Rev. 2001, 46, 3-26.

39. Zhao, Y.H.; Abraham, M.H.; Le, J.; Hersey, A.; Luscombe, C.N.; Beck, G.; Sherborne, B.; Cooper, I. Rate-limited steps of human oral absorption and QSAR studies. Pharm. Res. 2002, 19, 1446-1457.

40. Cheng, F.; Li, W.; Zhou, Y.; Shen, J.; Wu, Z.; Liu, G.; Lee, P.W.; Tang, Y. admetSAR: A comprehensive source and free tool for assessment of chemical ADMET properties. J. Chem. Inf. Model. 2012, 52, 3099-3105.

41. Barril, X., \& Luque, F. J. (2012). Molecular simulation methods in drug discovery: A prospective outlook. Journal of Computer-Aided Molecular Design, 26(1), 81-86. https://doi.org/10.1007/s10822-011-9506-1

42. Tatar, G., Ozyurt, E., \& Turhan, K. (2021). Computational drug repurposing study of the RNA binding domain of SARS-CoV-2 nucleocapsid protein with antiviral agents. Biotechnology Progress, 37(2) https://doi.org/ 10.1002/btpr.3110

43. M. A. Malik, S. A. Al-Thabaiti, and M. A. Malik, "Synthesis, structure optimization and antifungal screening of novel tetrazole ring bearing acyl-hydrazones," International Journal of Molecular Sciences, vol. 13, no. 9, pp. 10880-10898, 2012.

44. S. Dhingra and R. A. Cramer, "Regulation of sterol biosynthesis in the human fungal pathogen Aspergillus fumigatus: Opportunities for therapeutic development," Frontiers in Microbiology, vol. 8, article no. 92, 2017. 
45. A. Lupetti, R. Danesi, M. Campa, M. D. Tacca, and S. Kelly, "Molecular basis of resistance to azole antifungals," Trends in Molecular Medicine, vol. 8, no. 2, pp. 76-81, 2002. 

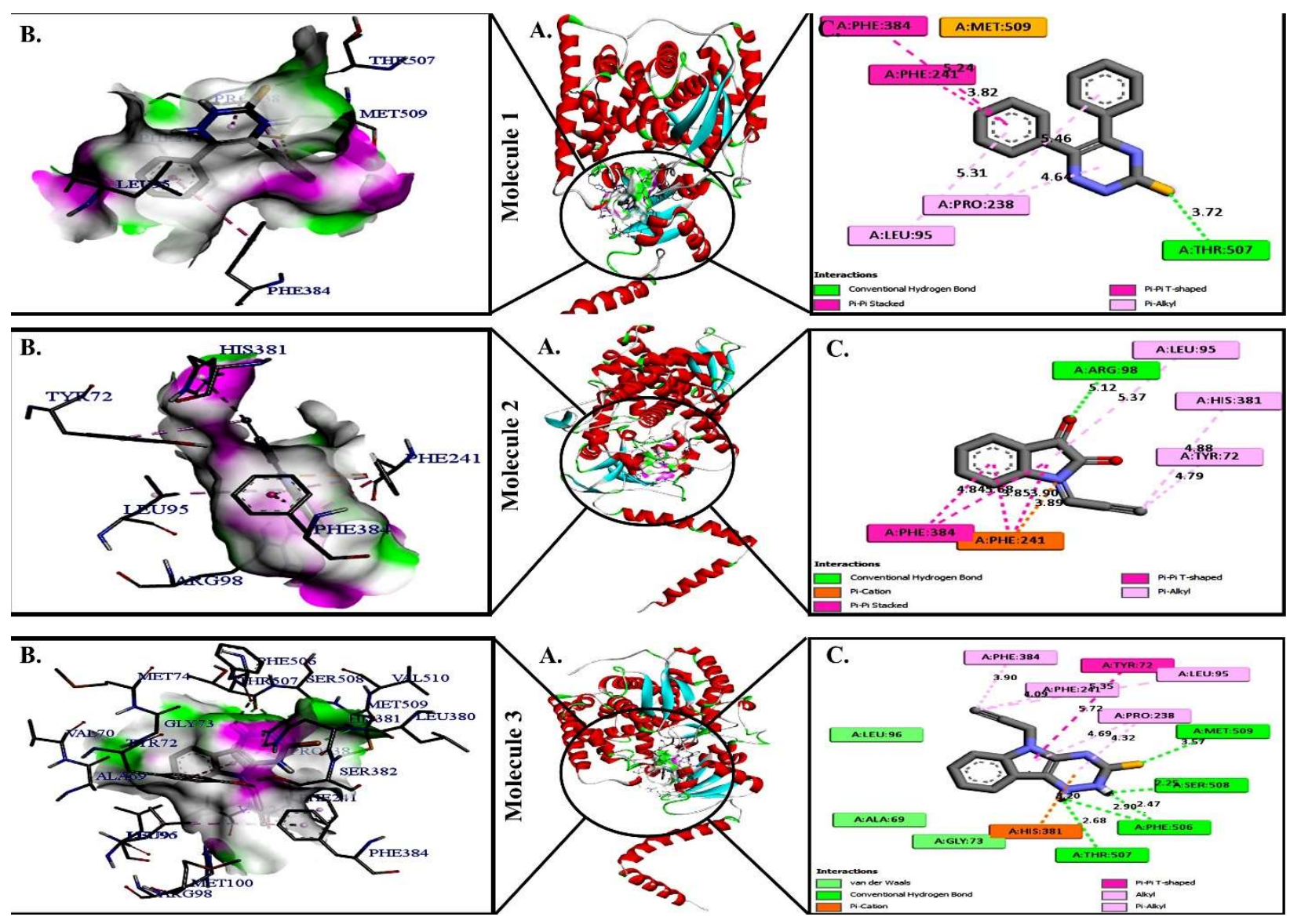

Figure 1. Protein-ligand presentation of Lanosterol 14 - demethylase (CYP51) with molecules. A depicted ribbon like receptor-ligand complex, B 3D receptor-ligand presentation and C. 2D receptor-ligand interactions. 

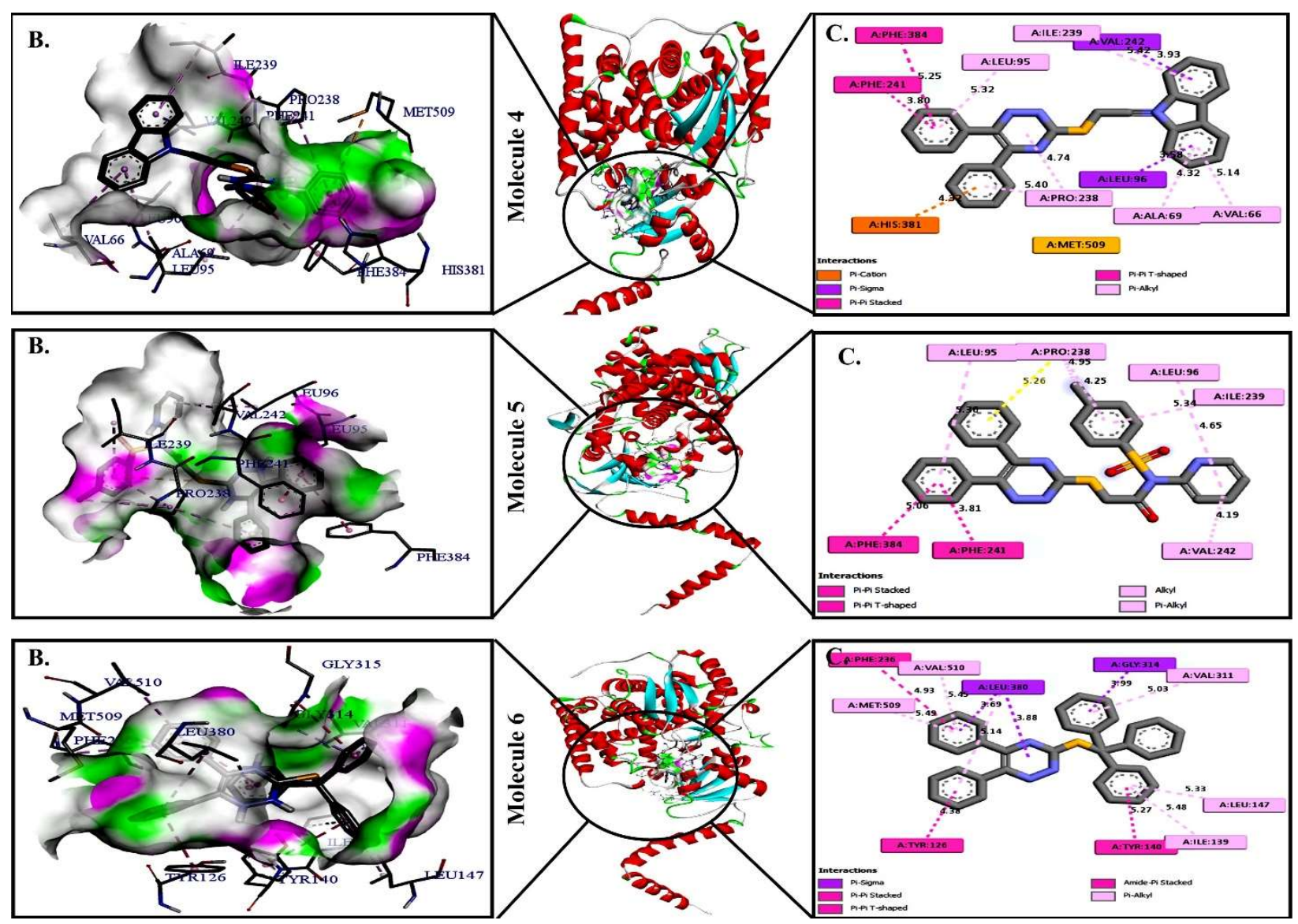

Figure 2. Protein-ligand presentation of Lanosterol 14 - demethylase (CYP51) with molecules. A depicted ribbon like receptor-ligand complex, B 3D receptor-ligand presentation and C. 2D receptor-ligand interactions. 


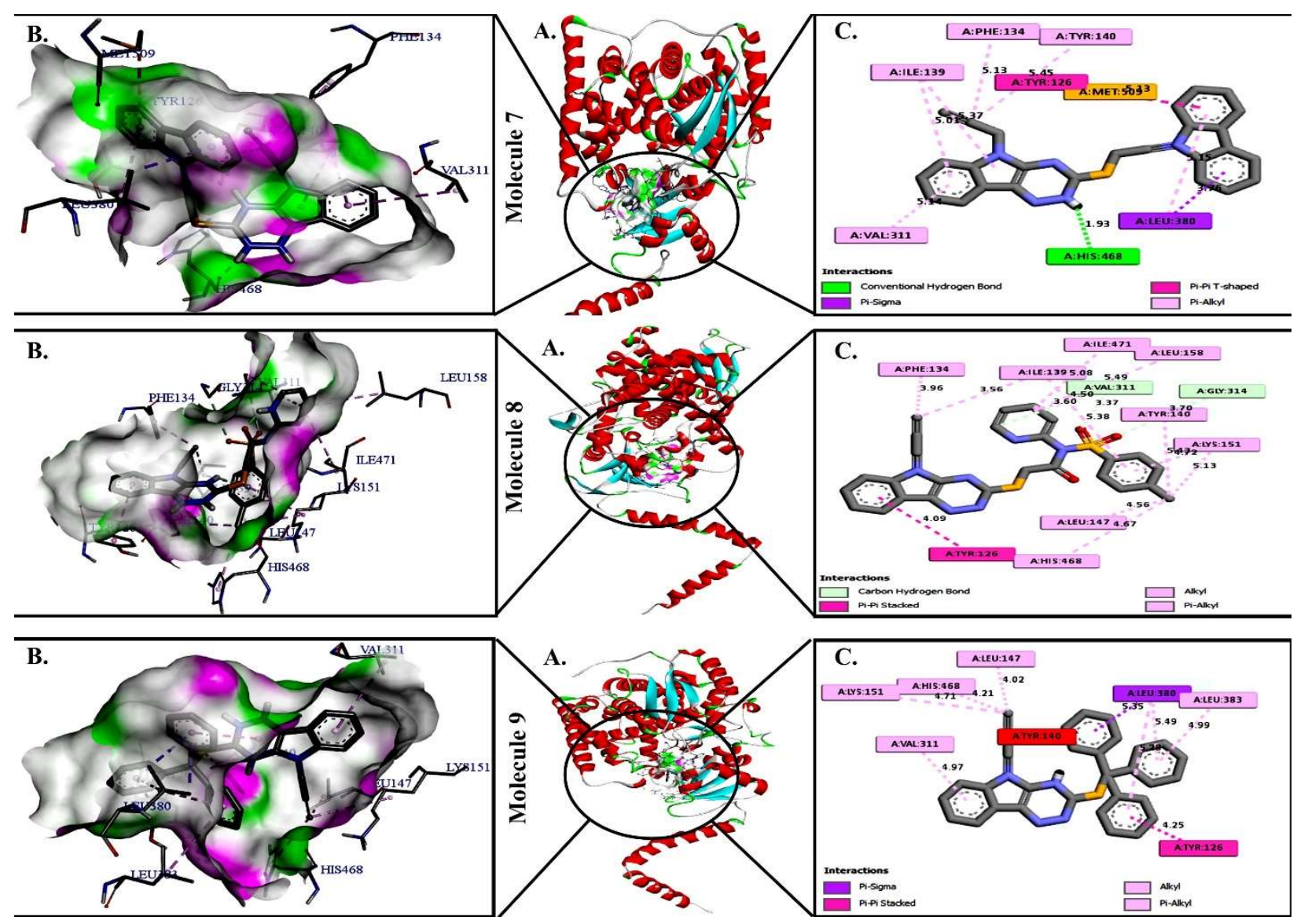

Figure 3. Protein-ligand presentation of Lanosterol 14 - demethylase (CYP51) with molecules. A depicted ribbon like receptor-ligand complex, B 3D receptor-ligand presentation and C. 2D receptor-ligand interactions. 

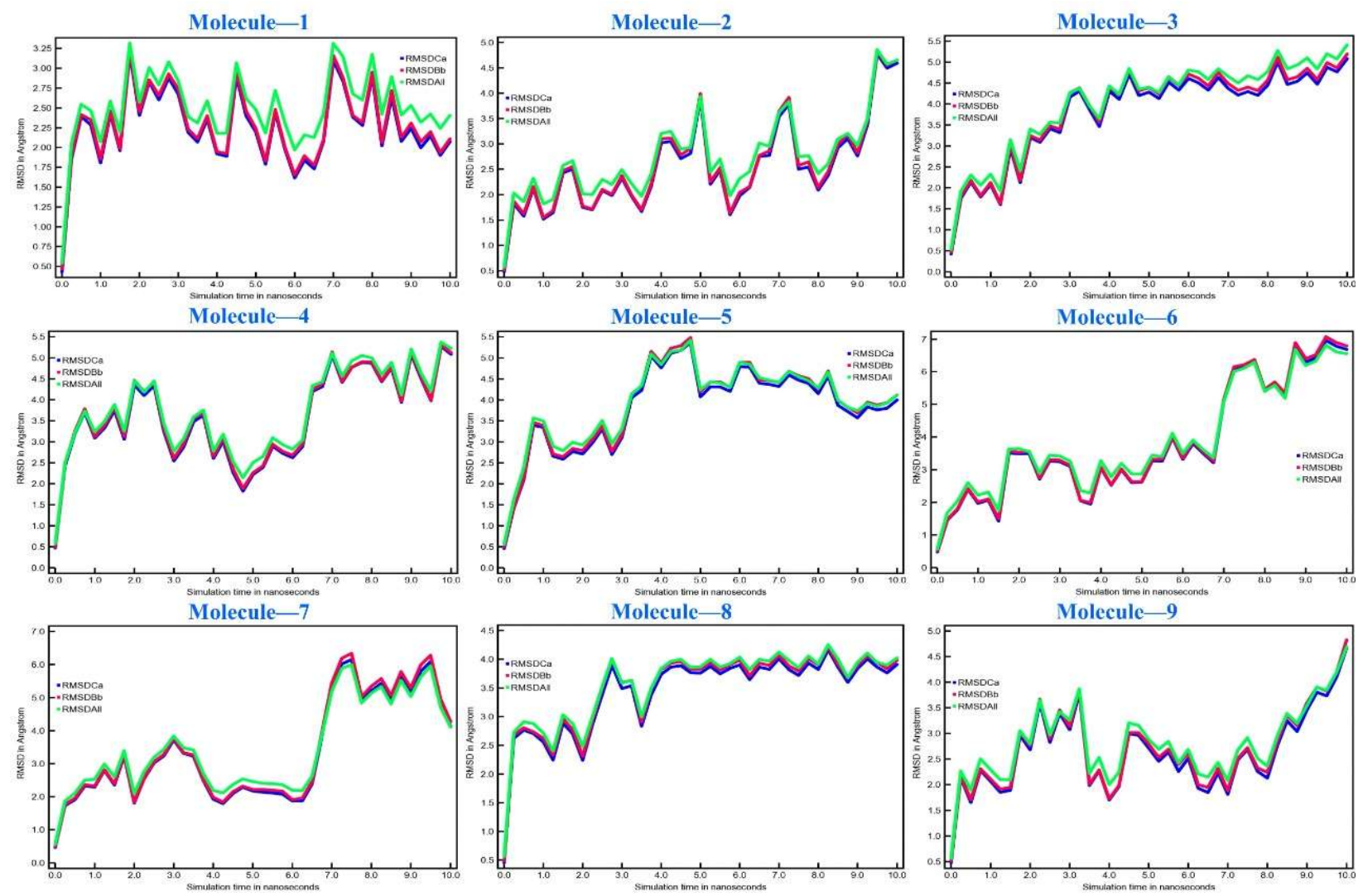

Figure 4 - Calculations of RMSD of Lanosterol 14 - demethylase (CYP51) and nine molecules as a function of $10 \mathrm{~ns}$ simulation time.
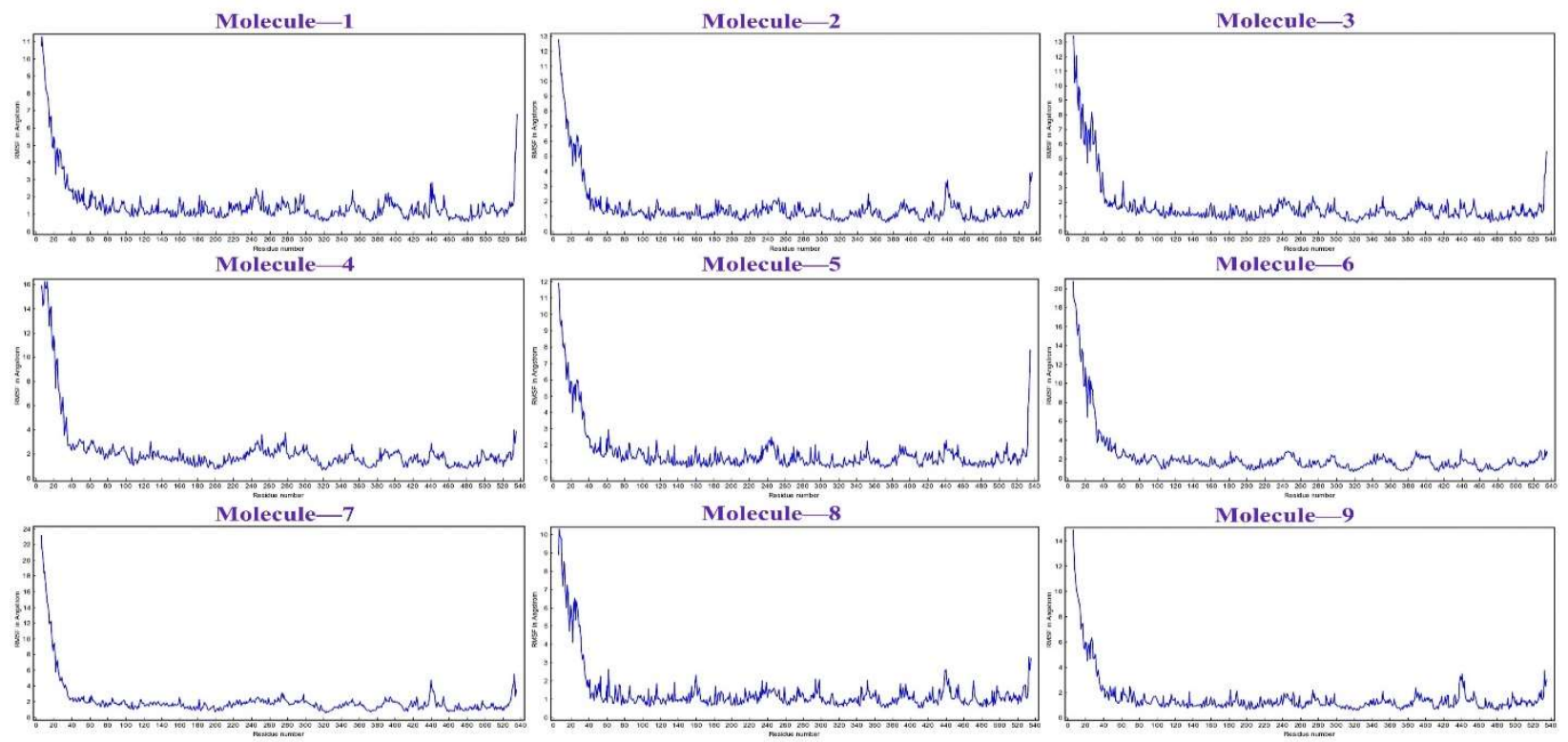

Figure 5. Calculations of the root mean square fluctuation per solute protein acid residue were calculated from the average RMSF of the atoms constituting the residue of Lanosterol 14 demethylase (CYP51) and nine molecules as a function of 10ns simulation time. 

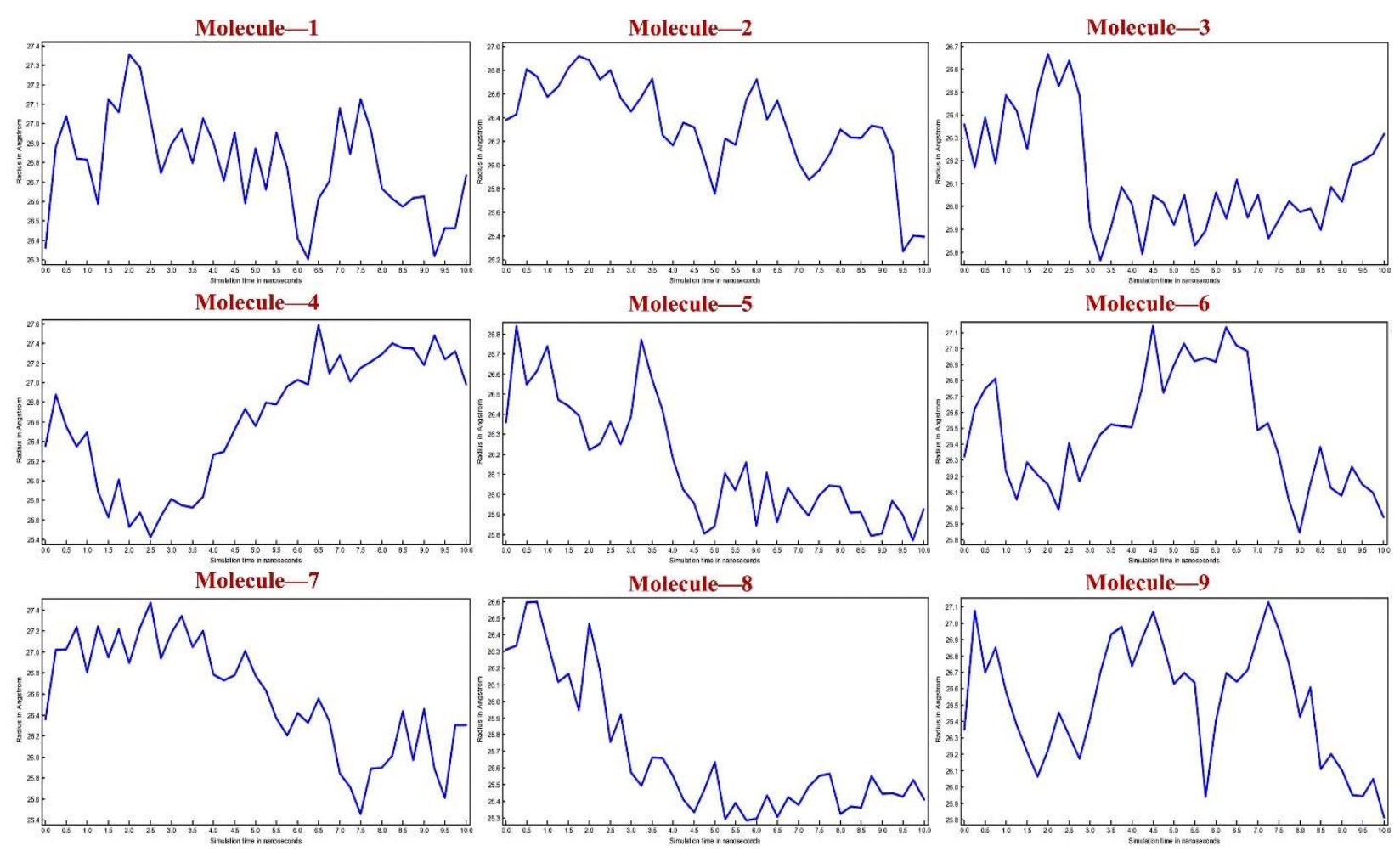

Figure 6- Calculations of Radius of gyration of the solute of Lanosterol 14 - demethylase (CYP51) and nine molecules as a function of $10 \mathrm{~ns}$ simulation time.
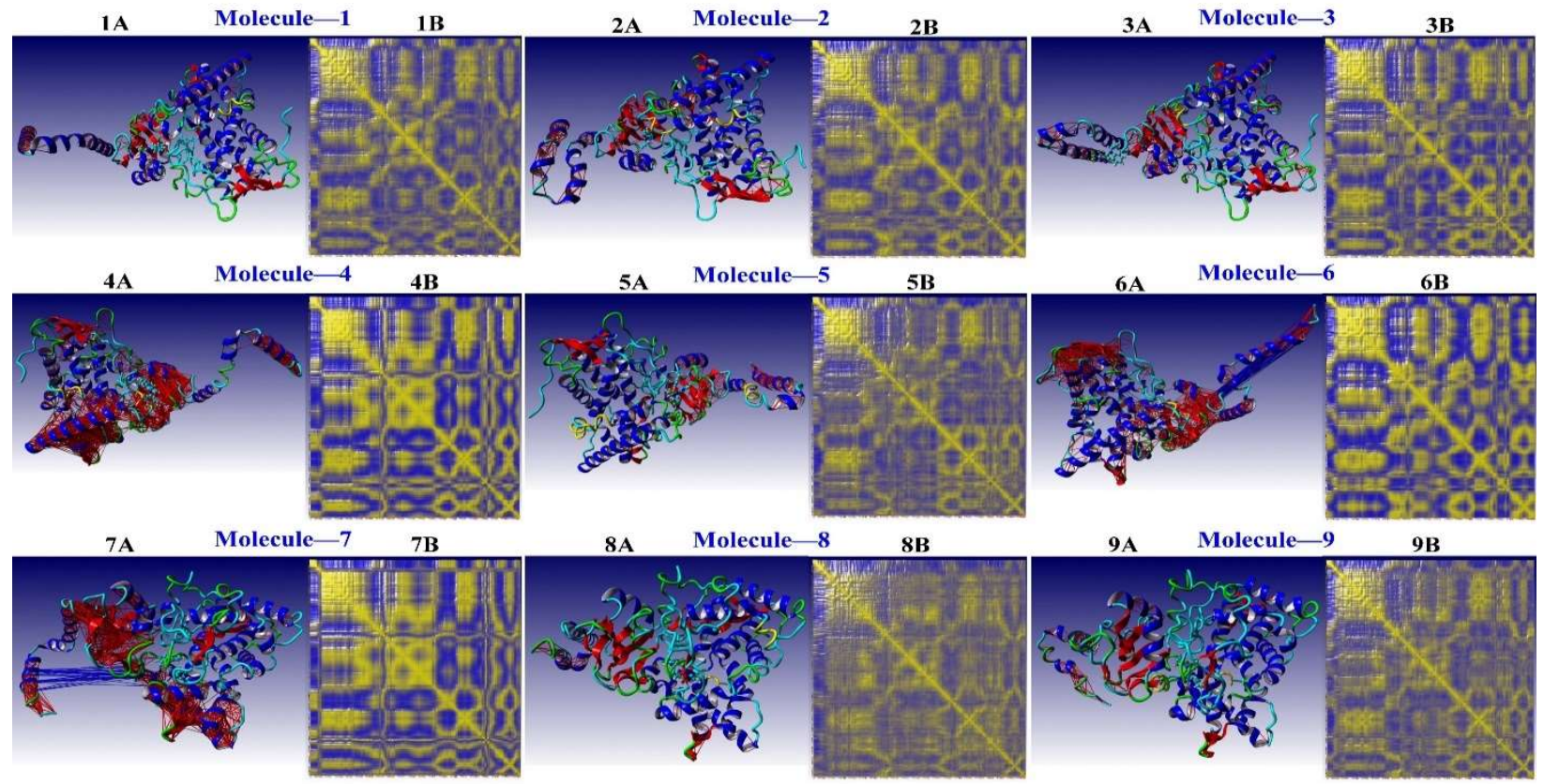

Figure 7. The residual correlative motion in protein structures was visualized by the dynamic cross-correlation map analysis for Lanosterol 14 - demethylase (CYP51). [Blue and Red lines are 
shown between strongly, anti- \& correlated pairs and DCCM is visualized with colours ranging from blue (-1, fully anti-correlated) to yellow $(+1$, fully correlated $)]$.
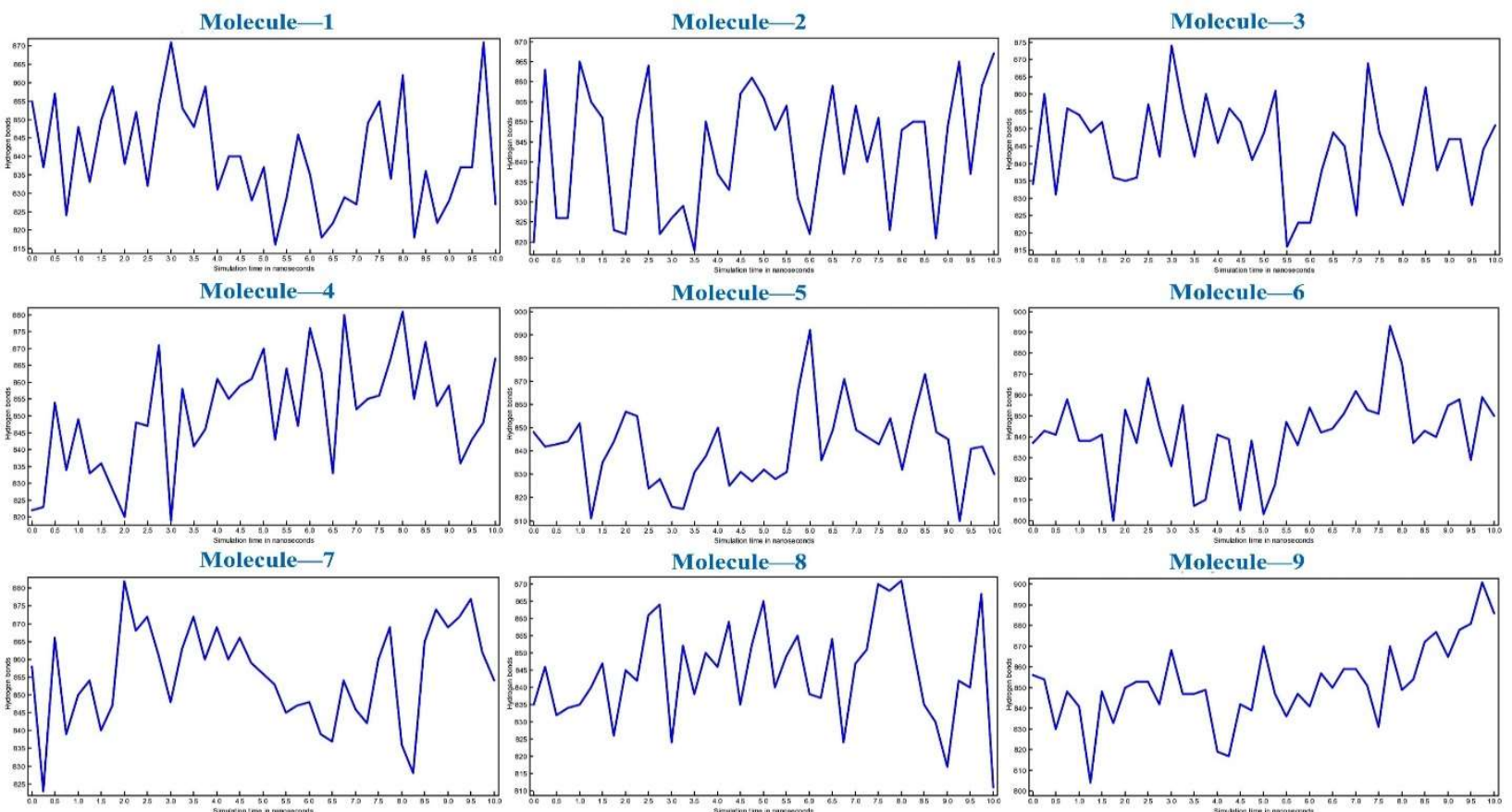

Figure 8. Calculations of No. of H-bonds between solute and solvent of Lanosterol 14 demethylase (CYP51) and nine molecules as a function of 10ns simulation time.

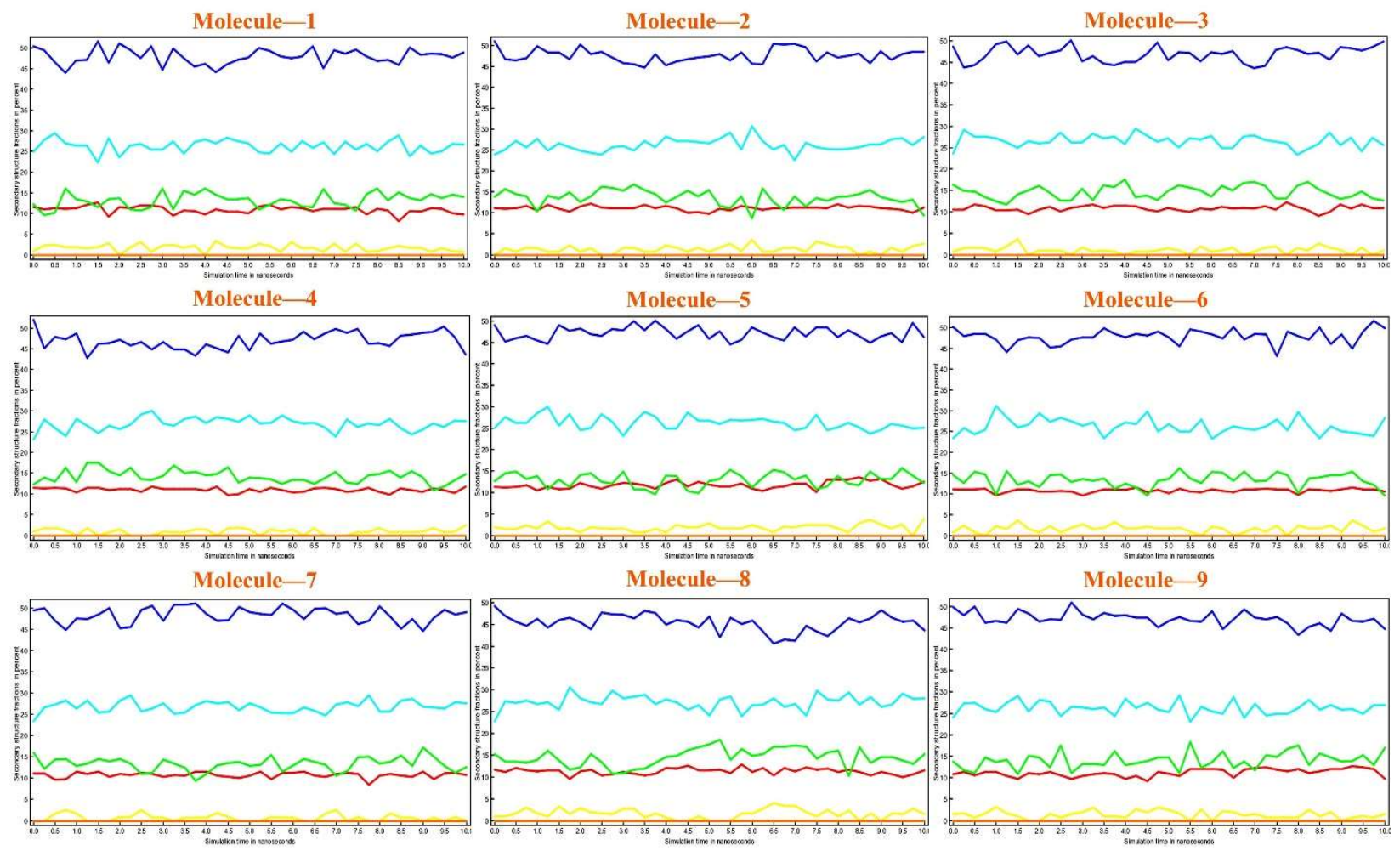


Figure 9. Protein secondary structure content calculations of Lanosterol 14 - demethylase (CYP51) and nine molecules as a function of 10ns simulation time.
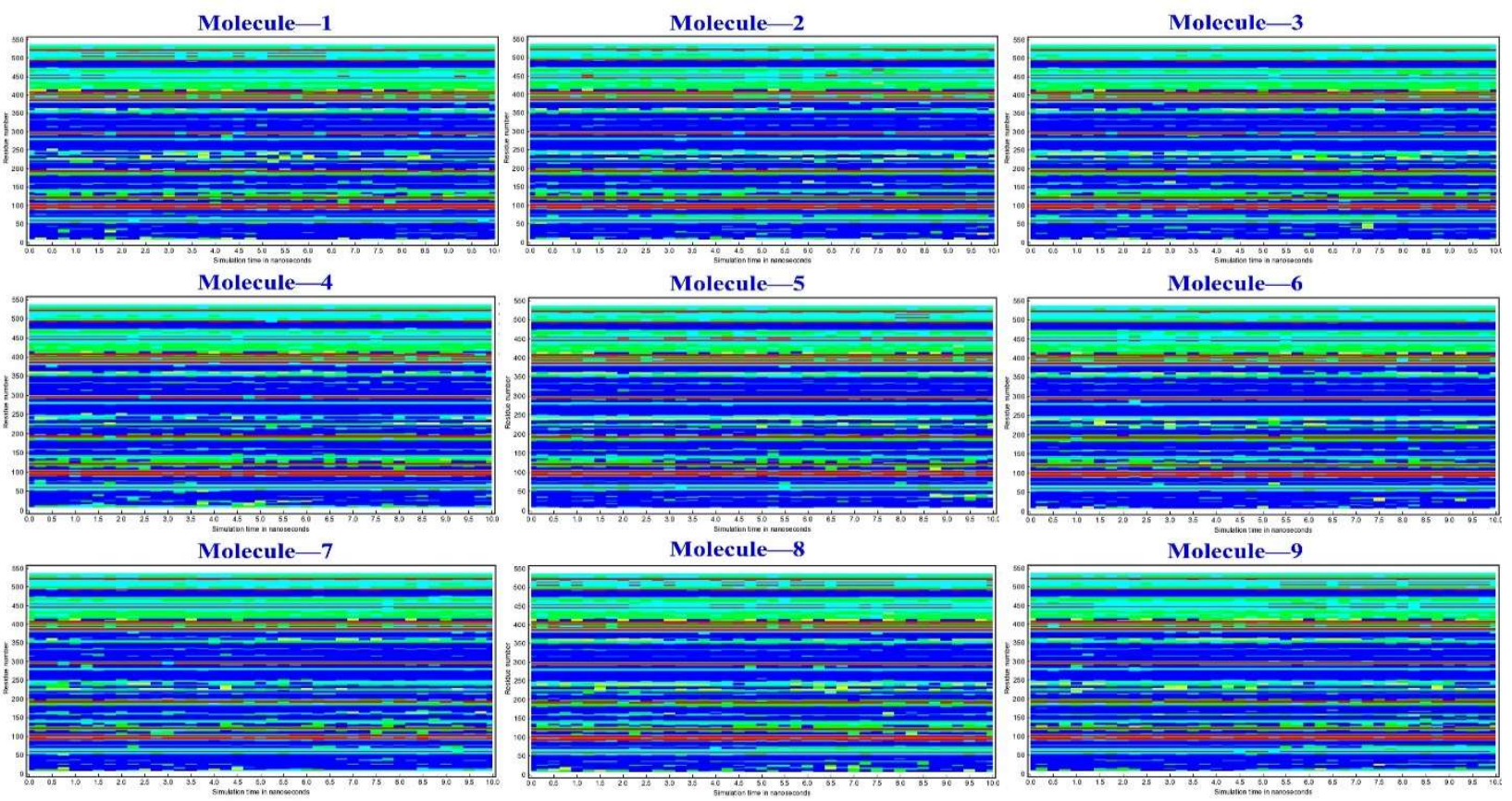

Figure 10 - Calculations of Per-residue protein secondary structure of Lanosterol 14 - demethylase (CYP51) and nine molecules as a function of 10ns simulation time.

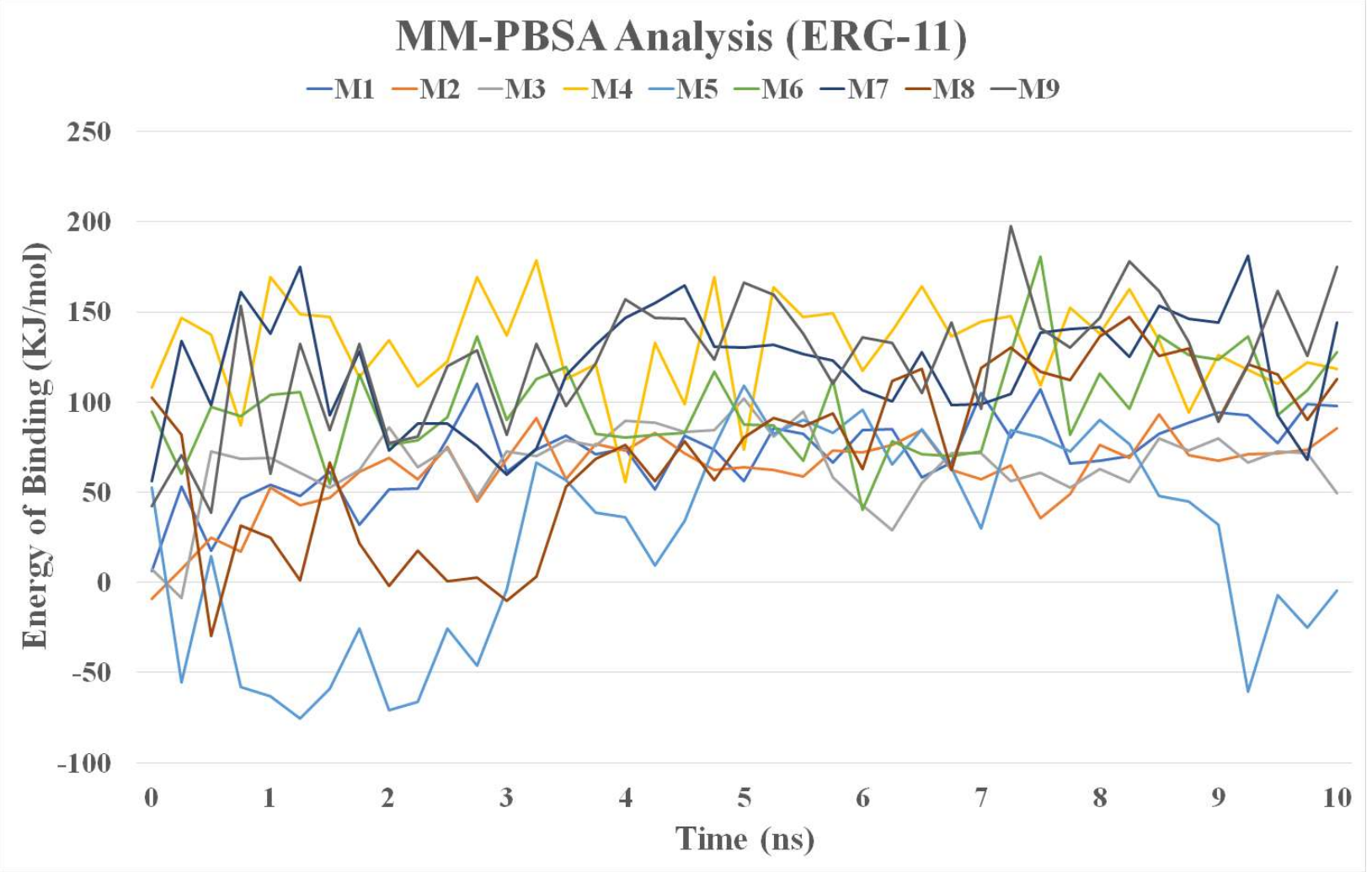


Figure 11. MM-PBSA analysis of nine molecules with Lanosterol 14 - demethylase (CYP51) during 10ns MD simulation time.

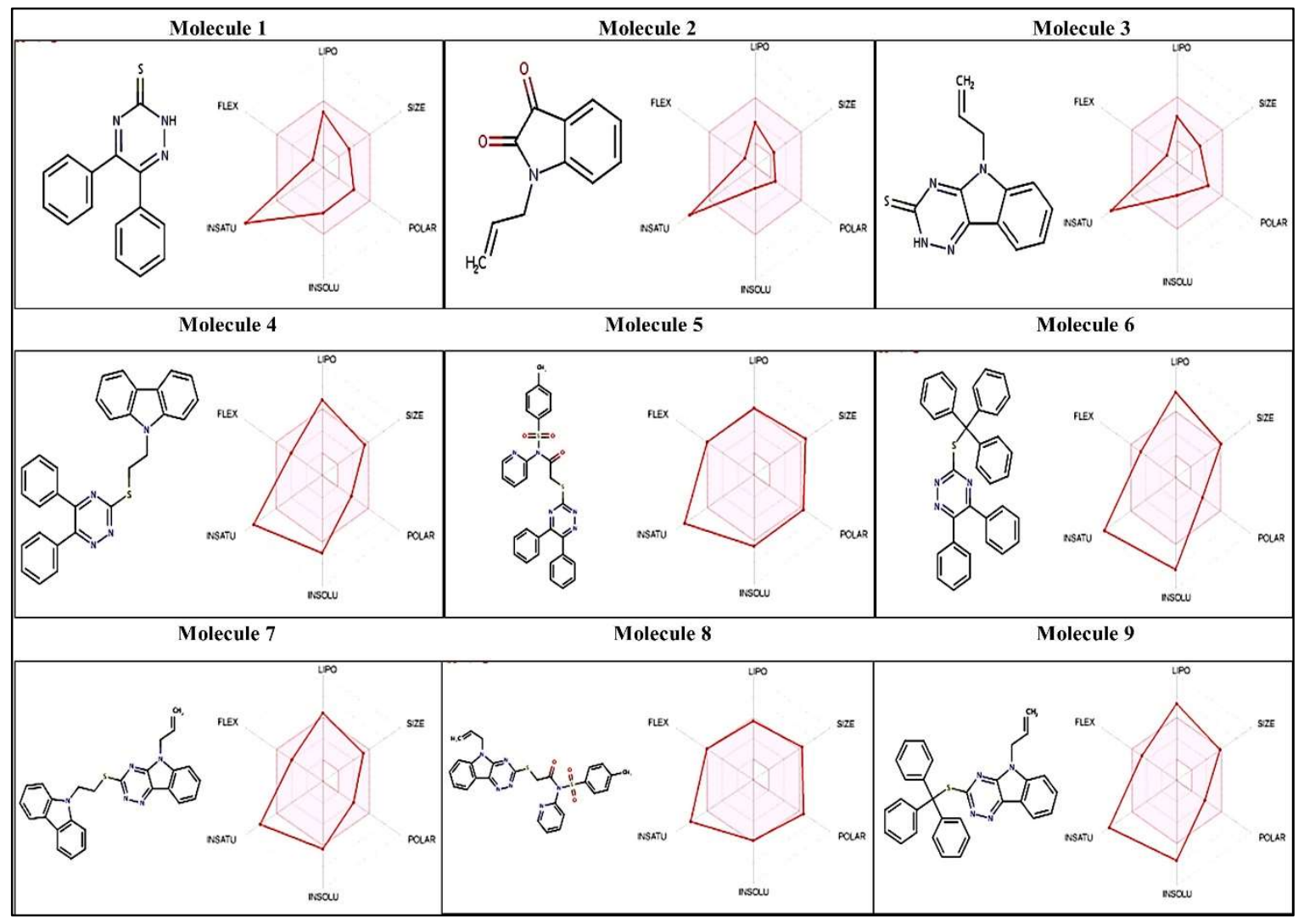

Figure 12- All the nine compounds show in a coloured zone are suitable physiochemical space for oral bioavailability and show the LIPO (Lipophilicity), SIZE (Molecular Weight), POLAR (Polarity), INSOLU (Insolubility), INSATU (Instauration), and FLIX (Rotatable bond flexibility) parameters. 


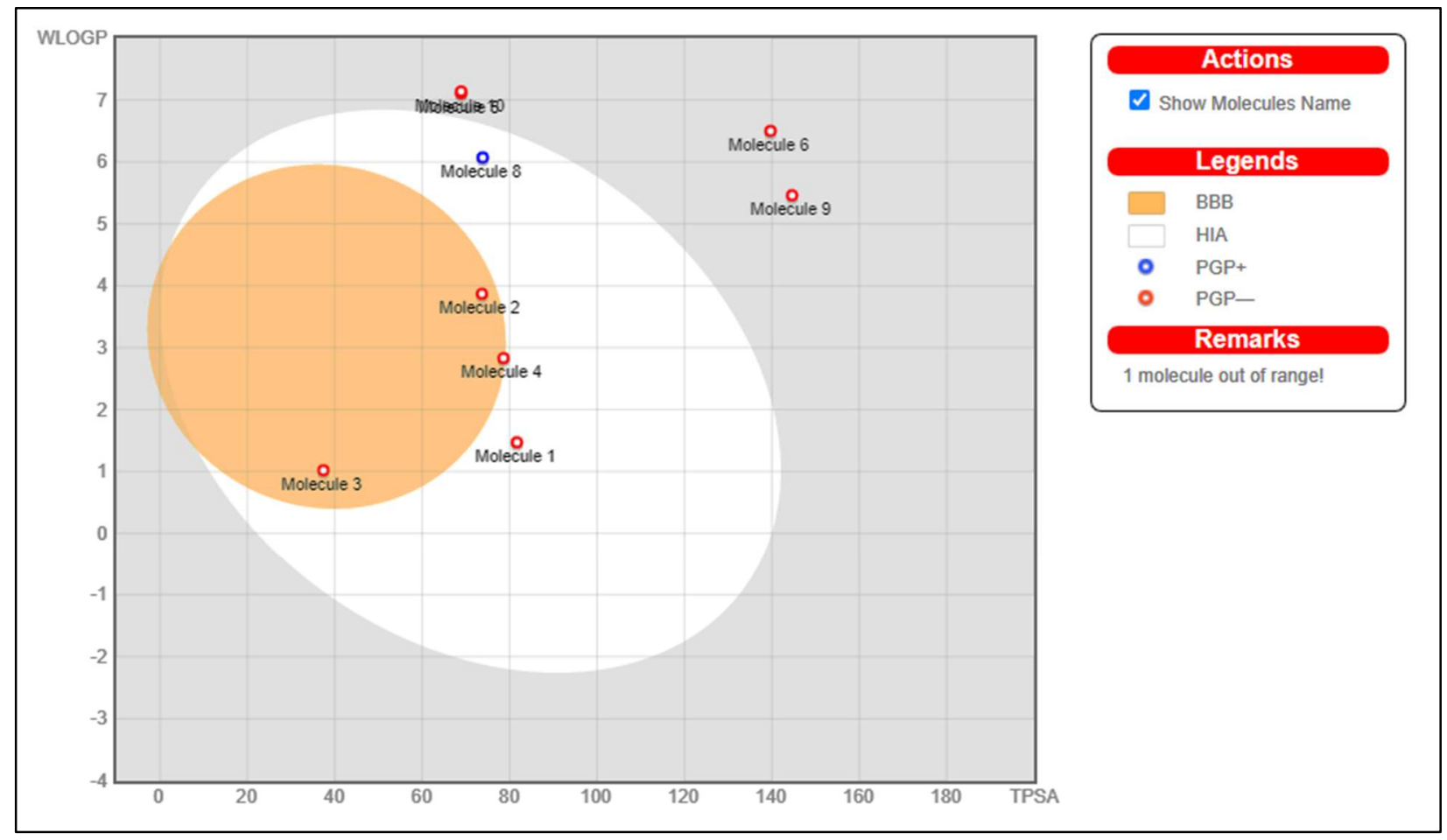

Figure 13- Boiled egg diagram and bioavailability radar map of nine compounds and control. (In Figure depicts molecule 1 is control and molecule 2 to 10 is compounds). 
Table 1. List of amino acids in the active site pocket of Lanosterol 14 - demethylase (CYP51) obtained from CASTp Web server.

\begin{tabular}{lll}
\hline Targeted Proteins & Chain & Amino Acids Present In Active Site Pockets \\
\hline Lanosterol 14 - demethylase & A Chain & Glu173, Lys176, Tyr177, Arg179, Asp180, Ser181, Lys182, Asn183, Arg185, Asn187, \\
(CYP51) & & Glu188, Met197, Va198, Pro201, Glu202, Ile205, Phe206, Arg218, Leu221, Asp222, \\
& Thr223, Ala226, Tyr227, Tyr229, Ser230, Leu232, Asp233, Lys234, Ile261, Tyr265, \\
& $\begin{array}{l}\text { Ile309, Leu312, Met313, Gln316, His317, Ala320, Ala321, Va1510, Leu512, His534, } \\
\text { His535 }\end{array}$ \\
\hline
\end{tabular}

Table 2. Docking score (Kcal/mol) of the Lanosterol 14 - demethylase (CYP51) with nine molecules.

\begin{tabular}{|c|c|c|}
\hline Molecules & Compounds Names & $\begin{array}{c}\text { ERG11 } \\
\text { Dock Score (Kcal/mol) }\end{array}$ \\
\hline Control & Fluconazole & -8.1 \\
\hline 1. & $1,2,4$-Triazine & -9.5 \\
\hline 2. & 1-(prop-2-en-1-yl)-1H-indole-2,3-dione & -8.2 \\
\hline 3. & 5-(prop-2-en-1-yl)-5H-[1,2,4] triazino [5,6-b]indole-3-thiol & -8.5 \\
\hline 4. & 2-((5,6-diphenyl-1,2,4-triazin-3-yl)thio)-N-(pyridin-2-yl)-N-tosylacetamide & -11.5 \\
\hline 5. & 2-(2-((5,6-diphenyl-1,2,4-triazin-3-yl)thio)ethoxy)isoindoline-1,3-dione & -11.0 \\
\hline 6. & 5,6-diphenyl-3-(tritylthio)-1,2,4-triazine & -11.9 \\
\hline 7. & 3-((2-(9H-carbazol-9-yl)ethyl)thio)-5-allyl-5H-[1,2,4]triazino[5,6-b]indole & -10.7 \\
\hline 8. & 2-((5-allyl-5H-[1,2,4]triazino[5,6-b]indol-3-yl)thio)- $N$-(pyridin-2-yl)- $N$-tosylacetamide & -10.5 \\
\hline 9. & 5-allyl-3-(tritylthio)-5H-[1,2,4]triazino $[5,6-\mathrm{b}]$ indole & -11.5 \\
\hline
\end{tabular}


Table 3. Protein-Ligand interactions profile of the Lanosterol 14 - demethylase (CYP51) (PDB id- 4LXJ) with nine molecules.

\begin{tabular}{|c|c|c|c|c|c|c|c|}
\hline $\begin{array}{l}\mathrm{N}^{0} \\
\text { Compounds }\end{array}$ & Molecule Name & $\begin{array}{l}\text { Conventional } \\
\text { Hydrogen Bond } \\
\text { Interactions with } \\
\text { distance }\end{array}$ & $\begin{array}{c}\text { Carbon } \\
\text { Hydrogen } \\
\text { Interactions } \\
\text { with distance }\end{array}$ & $\begin{array}{c}\pi-\sigma \\
\text { Interact } \\
\text { ions } \\
\text { with } \\
\text { distance } \\
\end{array}$ & $\begin{array}{l}\pi \text {-Alkyl \& Alkyl } \\
\text { interactions } \\
\text { with distance }\end{array}$ & $\begin{array}{l}\pi-\pi \text { Stacked/T- } \\
\text { Shaped Interactions } \\
\text { with distance }\end{array}$ & $\begin{array}{l}\text { Pi-Cation } \\
\text { and Anion } \\
\text { interactions } \\
\text { with } \\
\text { distance } \\
\end{array}$ \\
\hline 1. & 1,2,4-Triazine & Thr A: 507 (4.47) & - & - & $\begin{array}{l}\text { Leu A:95 (5.92), } \\
\text { Pro A:238 (5.06), } \\
\text { Pro A:238 (5.04) }\end{array}$ & $\begin{array}{ll}\text { Phe A:384 (7.09), } & \text { Phe } \\
\text { A:241 (4.35), } & \text { Met } \\
\text { A:509 (6.15) } & \end{array}$ & - \\
\hline 2. & $\begin{array}{l}\text { 1-(prop-2-en-1-yl)-1H- } \\
\text { indole-2,3-dione }\end{array}$ & Arg A:98 (5.12) & - & - & $\begin{array}{l}\text { His A:381 (5.88), } \\
\text { Leu A:95 (6.15), } \\
\text { Tyr A:72 (5.48) }\end{array}$ & $\begin{array}{l}\text { Phe A:384 } \quad\left(\begin{array}{lll}6.66 \quad \& \\
6.27)\end{array}\right. \\
\end{array}$ & Phe A:241 \\
\hline 3. & $\begin{array}{l}\text { 5-(prop-2-en-1-yl)-5H- } \\
{[1,2,4] \text { triazino }[5,6-} \\
b] \text { indole-3-thiol }\end{array}$ & $\begin{array}{l}\text { Thr A:507 (3.88), } \\
\text { Phe A:506 (6.91 \& } \\
6.45) \text {, Ser A:508 } \\
(4.43) \text {, Met A:509 } \\
(4.40)\end{array}$ & - & - & $\begin{array}{l}\text { Pro A:238 }(5.01), \\
\text { Leu A:95 }(5.90), \\
\text { Phe A:241 }(4.67), \\
\text { Phe A:384 }(4.98)\end{array}$ & Tyr A:72 (6.35) & His A:381 \\
\hline 4. & $\begin{array}{l}\text { 2-((5,6-diphenyl-1,2,4- } \\
\text { triazin-3-yl)thio)-N- } \\
\text { (pyridin-2-yl)-N- } \\
\text { tosylacetamide }\end{array}$ & - & - & $\begin{array}{c}\text { Leu } \\
\text { A:96 } \\
(5.32) \\
\text { Val } \\
\text { A:242 } \\
(5.65)\end{array}$ & $\begin{array}{l}\text { Leu A:95 }(5.91), \\
\text { Ala A:69 }(6.57), \\
\text { Val A:66 }(6.57), \\
\text { Ile A:239 }(6.70), \\
\text { Pro A:238 }(4.98 \\
\text { \& 5.19) }\end{array}$ & $\begin{array}{l}\text { Phe A:384 (6.96), Phe } \\
\text { A:241 (4.28) }\end{array}$ & $\begin{array}{l}\text { His } \mathrm{A}: 381 \\
(6.62)\end{array}$ \\
\hline
\end{tabular}




\begin{tabular}{|c|c|c|c|c|c|c|c|}
\hline 5. & $\begin{array}{l}\text { 2-(2-((5,6-diphenyl-1,2,4- } \\
\text { triazin-3- } \\
\text { yl)thio)ethoxy)isoindoline- } \\
1,3 \text {-dione }\end{array}$ & - & - & - & $\begin{array}{l}\text { Pro A:238 }(4.64), \\
\text { Ile A:239 }(5.16), \\
\text { Val A:242 }(4.58), \\
\text { Leu A:96 }(5.99), \\
\text { Leu A:95 }(5.47)\end{array}$ & $\begin{array}{l}\text { Phe A:384 (6.68), Phe } \\
\text { A:241 (4.45) }\end{array}$ & - \\
\hline 6. & $\begin{array}{l}\text { 5,6-diphenyl-3-(tritylthio)- } \\
\text { 1,2,4-triazine }\end{array}$ & - & - & $\begin{array}{c}\text { Gly } \\
\text { A:314 } \\
(4.21) \\
\text { Leu } \\
\text { A:380 } \\
(6.47 \\
\& 5.15)\end{array}$ & $\begin{array}{l}\text { Val A:311 (5.84), } \\
\text { Val A:510 (6.87), } \\
\text { Met A:509 (6.87), } \\
\text { Leu A:147 (7.23), } \\
\text { Ile A:139 (5.96) }\end{array}$ & $\begin{array}{ll}\text { Phe A:236 (6.95), Tyr } \\
\text { A:126 (5.34), } & \text { Tyr } \\
\text { A:140 (6.73) } & \end{array}$ & - \\
\hline 7. & $\begin{array}{l}\text { 3-((2-(9H-carbazol-9- } \\
\text { yl)ethyl)thio)-5-allyl-5H- } \\
{[1,2,4] \text { triazino[5,6- }} \\
\text { b]indole }\end{array}$ & $\begin{array}{l}\text { His A:468 } \\
(5.22)\end{array}$ & - & $\begin{array}{c}\text { Leu } \\
\text { A:380 } \\
(5.04)\end{array}$ & $\begin{array}{l}\text { Ile A:139 } \\
(5.97), \text { Val A:311 } \\
(6.17), \text { Tyr A:140 } \\
(6.04), \text { Phe A:134 } \\
(7.01)\end{array}$ & Tyr A:126 (6.81) & - \\
\hline 8. & $\begin{array}{l}\text { 2-((5-allyl-5H- } \\
{[1,2,4] \text { triazino[5,6- }} \\
b] \text { indol-3-yl)thio)- } N- \\
\text { (pyridin-2-yl)- } N- \\
\text { tosylacetamide }\end{array}$ & - & $\begin{array}{c}\text { Gly A:314 } \\
(3.88), \text { Val } \\
\text { A:311 (5.06) }\end{array}$ & - & $\begin{array}{l}\text { Phe A:134 (5.21), } \\
\text { Ile A:139 }(4.27) \text {, } \\
\text { Ile A:471 }(5.07) \text {, } \\
\text { Leu A:158 }(6.46) \text {, } \\
\text { Tyr A:140 (6.32) }\end{array}$ & Tyr A:126 (5.01) & \\
\hline 9. & $\begin{array}{l}\text { 5-allyl-3-(tritylthio)-5H- } \\
{[1,2,4] \text { triazino }[5,6-} \\
\text { b]indole }\end{array}$ & - & - & $\begin{array}{l}\text { Leu } \\
\text { A:380 } \\
(5.35)\end{array}$ & $\begin{array}{l}\text { Val A:311 }(5.33), \\
\text { Leu A:147 }(4.72), \\
\text { Lys A:151 }(4.84), \\
\text { His A:468 }(3.59), \\
\text { Leu A:383 }(6.17), \\
\text { Leu A:380 }(5.97 \\
\& 5.67)\end{array}$ & Tyr A:126 (5.14) & - \\
\hline
\end{tabular}


Table 4 - Pharamcological Properties of Nine Synthetic Compounds according to DruLito Software.

\begin{tabular}{|c|c|c|c|c|c|c|c|c|c|c|c|c|c|c|c|c|}
\hline Molecules & $\begin{array}{l}\text { MW } \\
\text { (g/mol }\end{array}$ & $\log p$ & Alogp & HBA & HBD & $\begin{array}{l}\text { TPSA } \\
\left(\AA^{2}\right)\end{array}$ & $\%$ ABS & AMR & nRB & $\begin{array}{l}\text { N } \\
\text { Atom }\end{array}$ & $\begin{array}{l}\text { nAcidic } \\
\text { Group }\end{array}$ & $\mathbf{R C}$ & $\begin{array}{l}\text { nRigid } \\
\text { B }\end{array}$ & $\begin{array}{l}\text { nArom } \\
\text { Ring }\end{array}$ & nHB & SAlerts \\
\hline 1. & 459.98 & 6.418 & 4.734 & 4 & 0 & 65.62 & 86.36 & 164.53 & 7 & 36 & 0 & 6 & 34 & 6 & 4 & 2 \\
\hline 2. & 450.95 & 2.608 & 2.341 & 9 & 0 & 140.81 & 60.42 & 154.38 & 9 & 37 & 0 & 5 & 32 & 5 & 9 & 1 \\
\hline 3. & 413.99 & 5.23 & 5.23 & 5 & 0 & 68.86 & 85.24 & 143.47 & 6 & 32 & 0 & 6 & 31 & 6 & 5 & 1 \\
\hline 4. & 481.98 & 6.905 & 6.905 & 3 & 0 & 62.38 & 21.52 & 177.98 & 7 & 38 & 0 & 6 & 36 & 6 & 3 & 2 \\
\hline 5. & 529.94 & 3.095 & 3.095 & 8 & 0 & 137.57 & 61.53 & 167.84 & 9 & 39 & 0 & 5 & 34 & 5 & 8 & 1 \\
\hline 6. & 435.98 & 5.717 & 5.717 & 4 & 0 & 65.62 & 86.36 & 156.92 & 6 & 34 & 0 & 6 & 33 & 6 & 4 & 1 \\
\hline
\end{tabular}




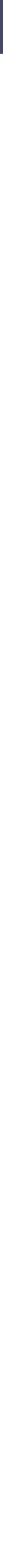

Table -5. Absorption, Distribution, and Metabolism of the nine molecules according to admetSAR online toolkit.

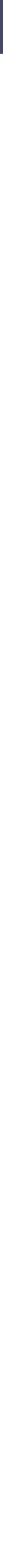




\begin{tabular}{|c|c|c|c|c|c|c|c|c|c|c|}
\hline & $\begin{array}{l}\text { P- } \\
\text { glycoprotein } \\
\text { Inhibitor }\end{array}$ & $\begin{array}{l}\text { Non- } \\
\text { Inhibitor }\end{array}$ & $\begin{array}{l}\text { Non- } \\
\text { Inhibitor }\end{array}$ & $\begin{array}{l}\text { Non- } \\
\text { Inhibitor }\end{array}$ & Inhibitor & $\begin{array}{l}\text { Non- } \\
\text { Inhibitor }\end{array}$ & $\begin{array}{l}\text { Non- } \\
\text { Inhibitor }\end{array}$ & $\begin{array}{l}\text { Non- } \\
\text { Inhibitor }\end{array}$ & $\begin{array}{l}\text { Non- } \\
\text { Inhibitor }\end{array}$ & $\begin{array}{l}\text { Non- } \\
\text { Inhibitor }\end{array}$ \\
\hline & $\begin{array}{l}\text { Renal } \\
\text { Organic } \\
\text { Cation } \\
\text { Transporter }\end{array}$ & $\begin{array}{l}\text { Non- } \\
\text { Inhibitor }\end{array}$ & $\begin{array}{l}\text { Non- } \\
\text { Inhibitor }\end{array}$ & $\begin{array}{l}\text { Non- } \\
\text { Inhibitor }\end{array}$ & Inhibitor & $\begin{array}{l}\text { Non- } \\
\text { Inhibitor }\end{array}$ & $\begin{array}{l}\text { Non- } \\
\text { Inhibitor }\end{array}$ & $\begin{array}{l}\text { Non- } \\
\text { Inhibitor }\end{array}$ & $\begin{array}{l}\text { Non- } \\
\text { Inhibitor }\end{array}$ & $\begin{array}{l}\text { Non- } \\
\text { Inhibitor }\end{array}$ \\
\hline Distribution & $\begin{array}{l}\text { Subcellular } \\
\text { localization }\end{array}$ & Mitochondria & Mitochondria & Mitochondria & Mitochondria & Mitochondria & Mitochondria & Mitochondria & $\begin{array}{l}\text { Plasma } \\
\text { membrane }\end{array}$ & Mitochondria \\
\hline \multirow{6}{*}{ Metabolism } & $\begin{array}{l}\text { CYP450 2C9 } \\
\text { Substrate }\end{array}$ & $\begin{array}{l}\text { Non- } \\
\text { Substrate }\end{array}$ & $\begin{array}{l}\text { Non- } \\
\text { Substrate }\end{array}$ & $\begin{array}{l}\text { Non- } \\
\text { Substrate }\end{array}$ & $\begin{array}{l}\text { Non- } \\
\text { Substrate }\end{array}$ & $\begin{array}{l}\text { Non- } \\
\text { Substrate }\end{array}$ & $\begin{array}{l}\text { Non- } \\
\text { Substrate }\end{array}$ & $\begin{array}{l}\text { Non- } \\
\text { Substrate }\end{array}$ & $\begin{array}{l}\text { Non- } \\
\text { Substrate }\end{array}$ & $\begin{array}{l}\text { Non- } \\
\text { Substrate }\end{array}$ \\
\hline & $\begin{array}{l}\text { CYP450 2D6 } \\
\text { Substrate }\end{array}$ & $\begin{array}{l}\text { Non- } \\
\text { Substrate }\end{array}$ & $\begin{array}{l}\text { Non- } \\
\text { Substrate }\end{array}$ & $\begin{array}{l}\text { Non- } \\
\text { Substrate }\end{array}$ & $\begin{array}{l}\text { Non- } \\
\text { Substrate }\end{array}$ & $\begin{array}{l}\text { Non- } \\
\text { Substrate }\end{array}$ & $\begin{array}{l}\text { Non- } \\
\text { Substrate }\end{array}$ & $\begin{array}{l}\text { Non- } \\
\text { Substrate }\end{array}$ & $\begin{array}{l}\text { Non- } \\
\text { Substrate }\end{array}$ & $\begin{array}{l}\text { Non- } \\
\text { Substrate }\end{array}$ \\
\hline & $\begin{array}{l}\text { CYP450 3A4 } \\
\text { Substrate }\end{array}$ & $\begin{array}{l}\text { Non- } \\
\text { Substrate }\end{array}$ & Substrate & $\begin{array}{l}\text { Non- } \\
\text { Substrate }\end{array}$ & $\begin{array}{l}\text { Non- } \\
\text { Substrate }\end{array}$ & $\begin{array}{l}\text { Non- } \\
\text { Substrate }\end{array}$ & $\begin{array}{l}\text { Non- } \\
\text { Substrate }\end{array}$ & $\begin{array}{l}\text { Non- } \\
\text { Substrate }\end{array}$ & $\begin{array}{l}\text { Non- } \\
\text { Substrate }\end{array}$ & $\begin{array}{l}\text { Non- } \\
\text { Substrate }\end{array}$ \\
\hline & $\begin{array}{l}\text { CYP450 1A2 } \\
\text { Inhibitor }\end{array}$ & Inhibitor & Inhibitor & Inhibitor & Inhibitor & $\begin{array}{l}\text { Non- } \\
\text { Inhibitor }\end{array}$ & Inhibitor & Inhibitor & $\begin{array}{l}\text { Non- } \\
\text { Inhibitor }\end{array}$ & Inhibitor \\
\hline & $\begin{array}{l}\text { CYP450 2C9 } \\
\text { Inhibitor }\end{array}$ & Inhibitor & $\begin{array}{l}\text { Non- } \\
\text { Inhibitor }\end{array}$ & $\begin{array}{l}\text { Non- } \\
\text { Inhibitor }\end{array}$ & $\begin{array}{l}\text { Non- } \\
\text { Inhibitor }\end{array}$ & Inhibitor & Inhibitor & $\begin{array}{l}\text { Non- } \\
\text { Inhibitor }\end{array}$ & Inhibitor & $\begin{array}{l}\text { Non- } \\
\text { Inhibitor }\end{array}$ \\
\hline & $\begin{array}{l}\text { CYP450 2D6 } \\
\text { Inhibitor }\end{array}$ & $\begin{array}{l}\text { Non- } \\
\text { Inhibitor }\end{array}$ & $\begin{array}{l}\text { Non- } \\
\text { Inhibitor }\end{array}$ & $\begin{array}{l}\text { Non- } \\
\text { Inhibitor }\end{array}$ & $\begin{array}{l}\text { Non- } \\
\text { Inhibitor }\end{array}$ & $\begin{array}{l}\text { Non- } \\
\text { Inhibitor }\end{array}$ & $\begin{array}{l}\text { Non- } \\
\text { Inhibitor }\end{array}$ & $\begin{array}{l}\text { Non- } \\
\text { Inhibitor }\end{array}$ & $\begin{array}{l}\text { Non- } \\
\text { Inhibitor }\end{array}$ & $\begin{array}{l}\text { Non- } \\
\text { Inhibitor }\end{array}$ \\
\hline
\end{tabular}

\begin{tabular}{|c|c|c|c|c|c|c|c|c|c|c|}
\hline & $\begin{array}{l}\text { P- } \\
\text { glycoprotein } \\
\text { Inhibitor }\end{array}$ & $\begin{array}{l}\text { Non- } \\
\text { Inhibitor }\end{array}$ & $\begin{array}{l}\text { Non- } \\
\text { Inhibitor }\end{array}$ & $\begin{array}{l}\text { Non- } \\
\text { Inhibitor }\end{array}$ & Inhibitor & $\begin{array}{l}\text { Non- } \\
\text { Inhibitor }\end{array}$ & $\begin{array}{l}\text { Non- } \\
\text { Inhibitor }\end{array}$ & $\begin{array}{l}\text { Non- } \\
\text { Inhibitor }\end{array}$ & $\begin{array}{l}\text { Non- } \\
\text { Inhibitor }\end{array}$ & $\begin{array}{l}\text { Non- } \\
\text { Inhibitor }\end{array}$ \\
\hline & $\begin{array}{l}\text { Renal } \\
\text { Organic } \\
\text { Cation } \\
\text { Transporter }\end{array}$ & $\begin{array}{l}\text { Non- } \\
\text { Inhibitor }\end{array}$ & $\begin{array}{l}\text { Non- } \\
\text { Inhibitor }\end{array}$ & $\begin{array}{l}\text { Non- } \\
\text { Inhibitor }\end{array}$ & Inhibitor & $\begin{array}{l}\text { Non- } \\
\text { Inhibitor }\end{array}$ & $\begin{array}{l}\text { Non- } \\
\text { Inhibitor }\end{array}$ & $\begin{array}{l}\text { Non- } \\
\text { Inhibitor }\end{array}$ & $\begin{array}{l}\text { Non- } \\
\text { Inhibitor }\end{array}$ & $\begin{array}{l}\text { Non- } \\
\text { Inhibitor }\end{array}$ \\
\hline Distribution & $\begin{array}{l}\text { Subcellular } \\
\text { localization }\end{array}$ & Mitochondria & Mitochondria & Mitochondria & Mitochondria & Mitochondria & Mitochondria & Mitochondria & $\begin{array}{l}\text { Plasma } \\
\text { membrane }\end{array}$ & Mitochondria \\
\hline \multirow{6}{*}{ Metabolism } & $\begin{array}{l}\text { CYP450 2C9 } \\
\text { Substrate }\end{array}$ & $\begin{array}{l}\text { Non- } \\
\text { Substrate }\end{array}$ & $\begin{array}{l}\text { Non- } \\
\text { Substrate }\end{array}$ & $\begin{array}{l}\text { Non- } \\
\text { Substrate }\end{array}$ & $\begin{array}{l}\text { Non- } \\
\text { Substrate }\end{array}$ & $\begin{array}{l}\text { Non- } \\
\text { Substrate }\end{array}$ & $\begin{array}{l}\text { Non- } \\
\text { Substrate }\end{array}$ & $\begin{array}{l}\text { Non- } \\
\text { Substrate }\end{array}$ & $\begin{array}{l}\text { Non- } \\
\text { Substrate }\end{array}$ & $\begin{array}{l}\text { Non- } \\
\text { Substrate }\end{array}$ \\
\hline & $\begin{array}{l}\text { CYP450 2D6 } \\
\text { Substrate }\end{array}$ & $\begin{array}{l}\text { Non- } \\
\text { Substrate }\end{array}$ & $\begin{array}{l}\text { Non- } \\
\text { Substrate }\end{array}$ & $\begin{array}{l}\text { Non- } \\
\text { Substrate }\end{array}$ & $\begin{array}{l}\text { Non- } \\
\text { Substrate }\end{array}$ & $\begin{array}{l}\text { Non- } \\
\text { Substrate }\end{array}$ & $\begin{array}{l}\text { Non- } \\
\text { Substrate }\end{array}$ & $\begin{array}{l}\text { Non- } \\
\text { Substrate }\end{array}$ & $\begin{array}{l}\text { Non- } \\
\text { Substrate }\end{array}$ & $\begin{array}{l}\text { Non- } \\
\text { Substrate }\end{array}$ \\
\hline & $\begin{array}{l}\text { CYP450 3A4 } \\
\text { Substrate }\end{array}$ & $\begin{array}{l}\text { Non- } \\
\text { Substrate }\end{array}$ & Substrate & $\begin{array}{l}\text { Non- } \\
\text { Substrate }\end{array}$ & $\begin{array}{l}\text { Non- } \\
\text { Substrate }\end{array}$ & $\begin{array}{l}\text { Non- } \\
\text { Substrate }\end{array}$ & $\begin{array}{l}\text { Non- } \\
\text { Substrate }\end{array}$ & $\begin{array}{l}\text { Non- } \\
\text { Substrate }\end{array}$ & $\begin{array}{l}\text { Non- } \\
\text { Substrate }\end{array}$ & $\begin{array}{l}\text { Non- } \\
\text { Substrate }\end{array}$ \\
\hline & $\begin{array}{l}\text { CYP450 1A2 } \\
\text { Inhibitor }\end{array}$ & Inhibitor & Inhibitor & Inhibitor & Inhibitor & $\begin{array}{l}\text { Non- } \\
\text { Inhibitor }\end{array}$ & Inhibitor & Inhibitor & $\begin{array}{l}\text { Non- } \\
\text { Inhibitor }\end{array}$ & Inhibitor \\
\hline & $\begin{array}{l}\text { CYP450 2C9 } \\
\text { Inhibitor }\end{array}$ & Inhibitor & $\begin{array}{l}\text { Non- } \\
\text { Inhibitor }\end{array}$ & $\begin{array}{l}\text { Non- } \\
\text { Inhibitor }\end{array}$ & $\begin{array}{l}\text { Non- } \\
\text { Inhibitor }\end{array}$ & Inhibitor & Inhibitor & $\begin{array}{l}\text { Non- } \\
\text { Inhibitor }\end{array}$ & Inhibitor & $\begin{array}{l}\text { Non- } \\
\text { Inhibitor }\end{array}$ \\
\hline & $\begin{array}{l}\text { CYP450 2D6 } \\
\text { Inhibitor }\end{array}$ & $\begin{array}{l}\text { Non- } \\
\text { Inhibitor }\end{array}$ & $\begin{array}{l}\text { Non- } \\
\text { Inhibitor }\end{array}$ & $\begin{array}{l}\text { Non- } \\
\text { Inhibitor }\end{array}$ & $\begin{array}{l}\text { Non- } \\
\text { Inhibitor }\end{array}$ & $\begin{array}{l}\text { Non- } \\
\text { Inhibitor }\end{array}$ & $\begin{array}{l}\text { Non- } \\
\text { Inhibitor }\end{array}$ & $\begin{array}{l}\text { Non- } \\
\text { Inhibitor }\end{array}$ & $\begin{array}{l}\text { Non- } \\
\text { Inhibitor }\end{array}$ & $\begin{array}{l}\text { Non- } \\
\text { Inhibitor }\end{array}$ \\
\hline
\end{tabular}




\begin{tabular}{|c|c|c|c|c|c|c|c|c|c|}
\hline $\begin{array}{l}\text { CYP450 } \\
2 \text { C19 } \\
\text { Inhibitor } \\
\end{array}$ & Inhibitor & $\begin{array}{l}\text { Non- } \\
\text { Inhibitor }\end{array}$ & Inhibitor & Inhibitor & Inhibitor & Inhibitor & Inhibitor & Inhibitor & Inhibitor \\
\hline $\begin{array}{l}\text { CYP450 3A4 } \\
\text { Inhibitor }\end{array}$ & Inhibitor & $\begin{array}{l}\text { Non- } \\
\text { Inhibitor }\end{array}$ & Inhibitor & Inhibitor & $\begin{array}{l}\text { Non- } \\
\text { Inhibitor }\end{array}$ & $\begin{array}{l}\text { Non- } \\
\text { Inhibitor }\end{array}$ & $\begin{array}{l}\text { Non- } \\
\text { Inhibitor }\end{array}$ & Inhibitor & Inhibitor \\
\hline $\begin{array}{l}\text { CYP } \\
\text { Inhibitory } \\
\text { Promiscuity }\end{array}$ & $\begin{array}{l}\text { High CYP } \\
\text { Inhibitory } \\
\text { Promiscuity }\end{array}$ & $\begin{array}{l}\text { High CYP } \\
\text { Inhibitory } \\
\text { Promiscuity }\end{array}$ & $\begin{array}{l}\text { High CYP } \\
\text { Inhibitory } \\
\text { Promiscuity }\end{array}$ & $\begin{array}{l}\text { High CYP } \\
\text { Inhibitory } \\
\text { Promiscuity }\end{array}$ & $\begin{array}{l}\text { High CYP } \\
\text { Inhibitory } \\
\text { Promiscuity }\end{array}$ & $\begin{array}{l}\text { High CYP } \\
\text { Inhibitory } \\
\text { Promiscuity }\end{array}$ & $\begin{array}{l}\text { High CYP } \\
\text { Inhibitory } \\
\text { Promiscuity }\end{array}$ & $\begin{array}{l}\text { High CYP } \\
\text { Inhibitory } \\
\text { Promiscuity }\end{array}$ & $\begin{array}{l}\text { High CYP } \\
\text { Inhibitory } \\
\text { Promiscuity }\end{array}$ \\
\hline
\end{tabular}

Table- 6 Toxicological properties of the molecules according to admetSAR online toolkit.

\begin{tabular}{|c|c|c|c|c|c|c|c|c|c|}
\hline \multirow[b]{2}{*}{ Parameters } & \multicolumn{9}{|c|}{ Molecules } \\
\hline & 1. & 2. & 3. & 4. & 5. & 6. & 7. & 8. & 9. \\
\hline Ames toxicity & $\begin{array}{l}\text { Non-AMES } \\
\text { toxic }\end{array}$ & $\begin{array}{l}\text { Non-AMES } \\
\text { toxic }\end{array}$ & $\begin{array}{l}\text { Non- } \\
\text { AMES } \\
\text { toxic }\end{array}$ & $\begin{array}{l}\text { Non- } \\
\text { AMES } \\
\text { toxic }\end{array}$ & $\begin{array}{l}\text { Non- } \\
\text { AMES } \\
\text { toxic }\end{array}$ & $\begin{array}{l}\text { Non-AMES } \\
\text { toxic }\end{array}$ & $\begin{array}{l}\text { Non- } \\
\text { AMES } \\
\text { toxic }\end{array}$ & $\begin{array}{l}\text { Non- } \\
\text { AMES } \\
\text { toxic }\end{array}$ & Non-AMES toxic \\
\hline
\end{tabular}




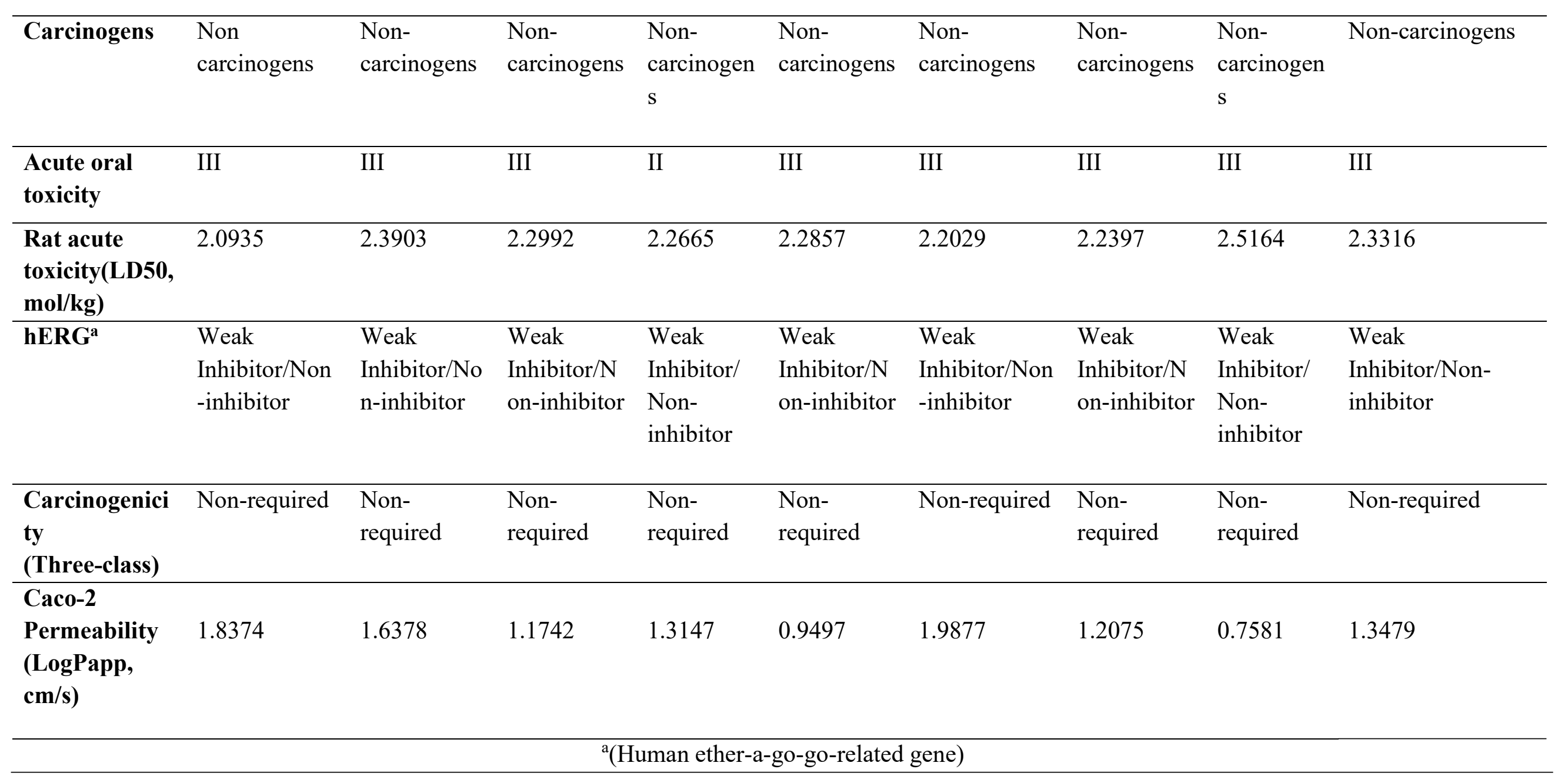




\author{
doi:10.20944/preprints202108.03
}

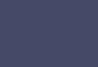

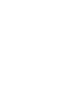
.

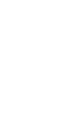

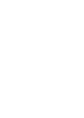

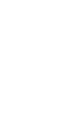

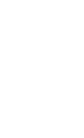
.

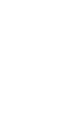

